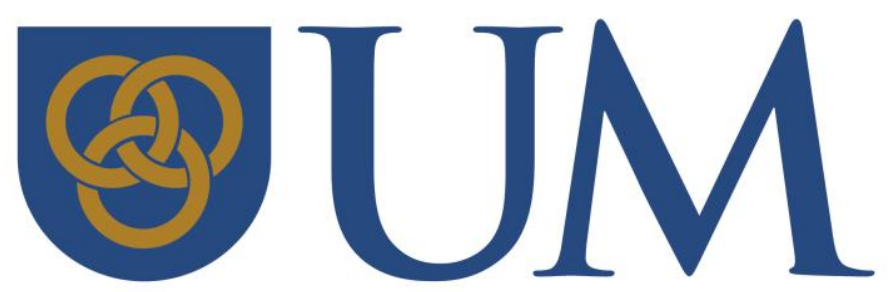

UNIVERSIDAD DE MONTEVIDEO

\author{
FACULTAD DE CIENCIAS EMPRESARIALES Y ECONOMIA
}

Serie de documentos de trabajo del Departamento de Economía /

Department of Economics Working Papers Series

\title{
Whistleblowers on the Board? The Role of Independent Directors in Cartel Prosecutions*
}

\author{
Murillo Campello
}

Daniel Ferrés

Gaizka Ormazabal

The working papers of the Department of Economics, Universidad de Montevideo are circulated for discussion and comment purposes. They have not been peer reviewed nor been subject to the review by the University's staff. (C) 2017 by Murillo Campello, Daniel Ferrés and Gaizka Ormazabal.

All rights reserved. Short sections of text, not to exceed two paragraphs, may be quoted without explicit permission provided that full credit, including $@$ notice, is given to the source. 


\title{
Whistleblowers on the Board? The Role of Independent Directors in Cartel Prosecutions*
}

\author{
Murillo Campello \\ Cornell University 8 \\ NBER \\ campello@cornell.edu
}

\author{
Daniel Ferrés \\ Universidad de Montevideo \\ dferres@um.edu.uy
}

\author{
Gaizka Ormazabal \\ IESE Business School \& \\ CEPR \\ gormazabal@iese.edu
}

This Draft: August 24, 2015

\begin{abstract}
Stock market reactions to news of cartel prosecutions are muted when indicted firms have a high proportion of independent directors serving on their boards. This finding is robust to self-selection and is more pronounced when those directors hold more outside directorships and have fewer stock options - when they have fewer economic ties to the indicted firms. Results are stronger when independent directors' appointments were attributable to SOX, preceded the CEO's appointment, or followed class action suits - when they have fewer direct ties to indicted CEOs. Independent directors serving on indicted firms are penalized by losing board seats and vote support across their directorships in other firms. Moreover, firms with more independent directors are more likely to cooperate with antitrust authorities through leniency programs and to dismiss CEOs after cartel indictments. Our results show that cartel prosecution imposes significant personal costs onto independent directors and that they take actions to reduce those costs. Understanding these incentives is key for antitrust authorities in designing strategies for cartel prosecution.
\end{abstract}

Key Words: Cartel Prosecution; Antitrust Policy; Leniency Programs; Independent Directors; Reputational Costs; Heckman Selection Test.

JEL Classification: G30, K21, L41.

*We thank Mireia Gine, Javier Gomez-Biscarri, Filippo Ippolito, Jose Luis Peydro, Xavier Vives, and seminar participants at IESE Business School, Lancaster University, Northwestern University, and Pompeu Fabra for useful comments and suggestions. Ormazabal acknowledges funding from the Ramon y Cajal and Marie Curie Fellowships. 


\title{
Whistleblowers on the Board? The Role of Independent Directors in Cartel Prosecutions*
}

\begin{abstract}
Stock market reactions to news of cartel prosecutions are muted when indicted firms have a high proportion of independent directors serving on their boards. This finding is robust to self-selection and is more pronounced when those directors hold more outside directorships and have fewer stock options - when they have fewer economic ties to the indicted firms. Results are stronger when independent directors' appointments were attributable to SOX, preceded the CEO's appointment, or followed class action suits - when they have fewer direct ties to indicted CEOs. Independent directors serving on indicted firms are penalized by losing board seats and vote support across their directorships in other firms. Moreover, firms with more independent directors are more likely to cooperate with antitrust authorities through leniency programs and to dismiss CEOs after cartel indictments. Our results show that cartel prosecution imposes significant personal costs onto independent directors and that they take actions to reduce those costs. Understanding these incentives is key for antitrust authorities in designing strategies for cartel prosecution.
\end{abstract}

Key Words: Cartel Prosecution; Antitrust Policy; Leniency Programs; Independent Directors; Reputational Costs; Heckman Selection Test.

JEL Classification: G30. 


\section{Introduction}

Price-fixing cartels are detrimental to a well-functioning economy as they enable colluding firms to secretly extract extraordinary, noncompetitive rents from the public. The magnitude of this problem is substantial and has been growing in an ever more globalized economy. The estimated volume of sales attributable to price-fixing cartels prosecuted between 1990 and 2013 surpasses $\$ 1.5$ trillion, with "overcharges" reaching, on average, $20 \%$ of observed prices (Connor and Bolotova (2006) and Connor (2014)). The widespread nature of cartel activity around the world is evidenced by the more than 7,000 companies named in 717 international cartel convictions in 70 different countries between 1990 and 2013.

Antitrust enforcement actions have increased after the wave of price-fixing scandals of the 1990s. ${ }^{1}$ They have gained renewed attention in recent years following public outrage over price manipulation cases involving the automotive industry and the setting of the LIBOR rate. Figure 1 shows that while less than 80 cartels were prosecuted per year before 2005, more than 120 were indicted annually between 2005 and 2010. Annual fines increased from less than $\$ 2$ billion to more than $\$ 7$ billion over the same period. Notably, an increasing number of cartels have been uncovered through voluntary applications to leniency programs. ${ }^{2}$

Despite the recent emphasis on antitrust enforcement, regulators disagree on how to implement strategies aimed at the detection and prosecution of cartels. The lack of consensus concerning these policies is evidenced by significant cross-country differences in the regulatory framework. ${ }^{3}$ This is an area where research is much needed and academic work can help guide more effective and uniform antitrust policies around a more integrated world economy.

Our paper contributes to the design of cartel discovery and prosecution policies. It does so by putting the spotlight on the role played by independent directors in cartel-indicted firms, before and after investigations become public. We show how the success of cartel detection and prosecution is affected by the degree to which corporate board members have economic ties to the firm. Corporations can be seen as the nexus of contracts among individuals with

\footnotetext{
${ }^{1}$ High-profile cases include the lysine pricing scandal involving ADM and the auction price conspiracy involving Sotheby's and Christie's.

${ }^{2} \mathrm{~A}$ leniency program defines rules for granting reductions in penalties to firms or individuals that selfreport participation in cartel activities and cooperate in the investigation of the enforcement authorities.

${ }^{3} \mathrm{~A}$ key difference between European and US antitrust laws is that the US legislation contemplates criminal sanctions not only for corporations but also for individuals. This discrepancy has created difficulties for the joint prosecution of cartels operating across those two jurisdictions.
} 


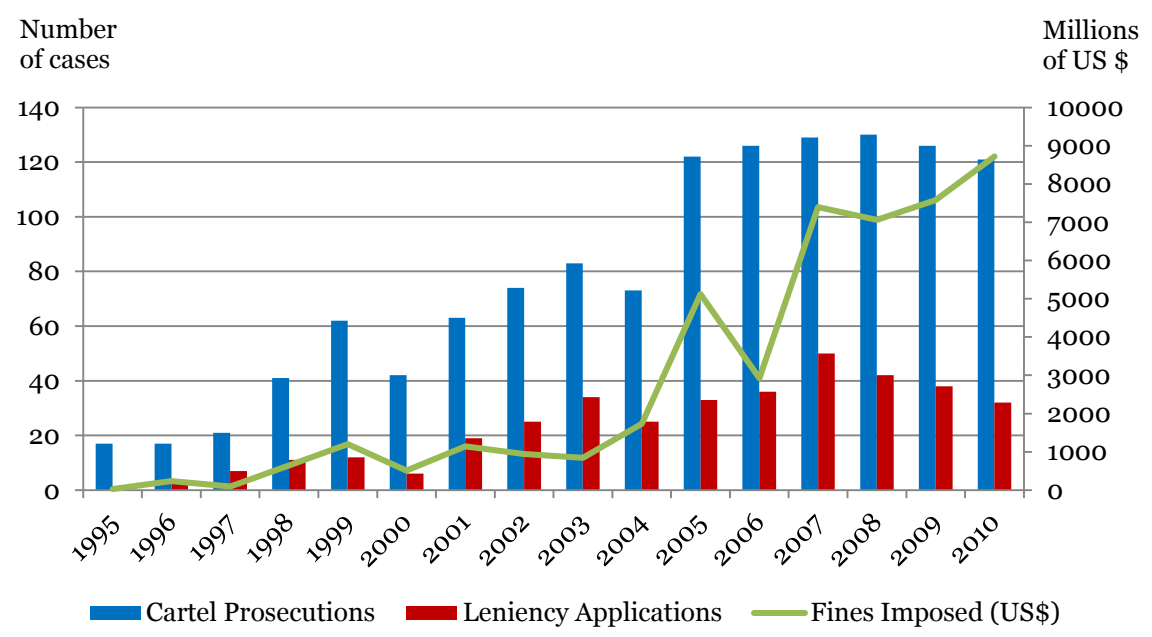

Figure 1. Cartel Prosecution Activity around the World. This figure plots data on the number of cartel prosecutions, leniency applications, and amount of fines between 1995 and 2010. The left vertical axis indicates number of cases and refers to cartel prosecutions and leniency applications. The right vertical axis indicates million dollars and refers to the total annual amount of imposed fines. Each indictment in a given jurisdiction is counted as one prosecution regardless of whether the cartel is prosecuted in another jurisdiction. Fines are aggregated in the year in which they are levied by each antitrust authority. Data are gathered from the PIC database.

different objectives. Although agency problems stemming from individuals' self-interest can lead to undesirable behaviors, they can also be used by prosecuting authorities. We posit that the misalignment of objectives of managers and directors - officials in the same organization - is a powerful friction for antitrust regulators to exploit in cartel prosecutions. As regulation is used to shape the board directorship of public corporations, we show additional positive externalities to the principle of requiring firms to have independent directors.

Managers and directors' preferences towards engaging in cartel activity differ significantly. Unlike managers, professional directors derive limited gains (at best) from pricefixing schemes as their equity holdings and other monetary interests in the firm are generally far less convex than those of managers. Involvement in cartel scandals, however, can bring significant costs for those professionals. First, because boards are legally responsible for overseeing managerial misconduct, directors may share in the legal liability stemming from cartel prosecution. ${ }^{4}$ But the reputational and personal wealth costs associated with cartel involvement are likely to weigh even higher on director's objective function. This is especially true for those directors that serve on the boards of several different companies, as the

\footnotetext{
${ }^{4}$ Cartel prosecutions sometimes entail individual sanctions, including monetary fines and imprisonment.
} 
reputational damage from cartel involvement may extend onto their other directorships.

On the other hand, the involvement of directors in the price-fixing schemes could be difficult to verify in court. Unlike financial reporting or the design of executive compensation, the detection of price-fixing activities is not a task attributable to any particular board member or committee. Whether the incentives associated with cartel involvement are significant enough to induce directors to take action - either in helping perpetrating cartels or denouncing them — and whether their induced behavior ultimately benefits or hurts shareholders is a question of much interest for regulators and researchers.

We examine the dynamics of cartel discoveries and prosecutions as a function of board independence. We do so looking at a comprehensive set of companies indicted by antitrust authorities across international jurisdictions between 2002 and 2012. As a starting point, we analyze the stock market reaction to news about cartel prosecutions. In particular, we model abnormal returns to cartel indictments and other antitrust rulings as a function of the proportion of independent directors serving in the firms cited. We find that the presence of independent directors reduces the cost of cartel prosecution to shareholders. Simply put, firms with larger proportions of independent directors on their boards observe significantly smaller value losses in cartel-busting episodes. The magnitude of the variation in equity returns is substantial. A conservative estimation suggests that a one-standard deviation increase in director independence - a mere 1 or 2-person increase in the number of independent directors in the average firm - is associated with nearly 100 basis points higher average one-day returns around announcements involving cartel investigations and indictments.

The finding that losses to shareholders around cartel prosecution news are modulated by the fraction of independent directors on company boards is robust to a number of checks. Results become stronger when we use a Heckman test to shore up our inferences against selection biases. ${ }^{5}$ We further employ an IV-like approach where we only explore the proportion of firms' independent directors that is driven by factors outside of the influence of indicted CEOs. In particular, we consider situations where independent directors' appointments were attributable to the passage of SOX, preceded the CEOs' own appointments, and followed class action suits. Our results suggest that the market responds even more favorably to the

\footnotetext{
${ }^{5}$ Notably, we show that the level of board independence in prosecuted firms is indistinguishable from that observed in the underlying industry-year population from which those firms are drawn.
} 
presence of these types of independent directors on the boards of indicted firms following news of cartel prosecutions. Beyond tests performed on de facto persecuted firms, we also explore the effect of prosecution on unprosecuted peer firms (e.g., firms operating in the same industry of the indicted firm). Similar to our tests on prosecuted firms, we find that when the expected probability of prosecution increases, unprosecuted firms also experience abnormal returns that are positively correlated with the proportion of independent directors on the board.

We further our interpretation of the role played by independent directors in cartel prosecutions by examining whether the association between stock returns and the presence of independent directors is motivated by personal costs stemming from public persecutions. We find that equity value losses from cartel indictments are lower when directors have a higher number of directorship appointments outside of the indicted firms. Those value losses are also lower when independent directors have fewer stock options, thus lower incentives to engage in firm-specific risk taking.

We corroborate our argument about independent directors' incentives by examining the personal costs they bear for their involvement with indicted firms. Our analysis shows that, after prosecution announcements, directors of firms involved in cartels depart from a significant number of directorships in other firms. Notably, even when they do not lose positions in other firms, they still lose voting support across their portfolio of outside directorships.

To better understand the patterns we document, we examine two additional dynamics that take place around cartel prosecutions. The first concerns leniency applications, a unique provision of antitrust regulation that is often used by board members so as to minimize personal costs of prosecution. ${ }^{6}$ In particular, we examine the association between the probability of applying for corporate leniency and the presence of independent directors on the board. We find that firms with a higher proportion of independent directors are more likely to apply for leniency in cartel prosecutions. Notably, we find that firms with a higher proportion of independent directors are also more likely to replace the scandal-laden CEO following prosecution announcements.

\footnotetext{
${ }^{6}$ Board members can single-handedly initiate investigations that eventually result in leniency applications. In 2009, Tecumseh Products (a large producer of refrigerant compressors) applied for leniency in a number of jurisdictions (US, EU, and Brazil) after an internal investigation directed by its board of directors uncovered the participation of managers in price-fixing dealings. The firm's audit committee was comprised by independent directors with multiple assignments in other firms.
} 
In all, the results we report are consistent with the idea that cartel prosecution bears significant costs for independent directors and that those directors take ex-ante and ex-post actions to mitigate their personal losses. Our analysis details the various market-based sanctions imposed onto independent directors involved in price-fixing scandals. The study suggests that these sanctions can be used to inform and rationalize regulatory actions around antitrust enforcement.

Our paper contributes to several strands of literature. First, it extends prior work on the effect of fraudulent activities on directors' reputation (see, among others, Agrawal et al. (1999), Fich and Shivdasani (2007), Ertimur et al. (2012), and Brochet and Srinivasan (2014)). Importantly, the existing papers do not look at cartel price-fixing schemes. Instead of looking at securities or accounting fraud, our analysis considers commercial fraud that yields economic benefits to firm insiders by extracting rents from other economic agents (consumers and other companies). Critically, cartel prosecution is associated with large stock market losses and thus provides a powerful setting to observe the effect of director's incentives. This is important considering that prior literature is inconclusive on whether reputational incentives are strong enough to prevent fraud.

Our work also has clear links to the literature on board composition and independence. Prior research has uncovered factors that adversely affect directors' ability to provide monitoring services, such as the number of directors on the board (Yermack (1996)), their other directorships (Fich and Shivdasani (2006)), and their connections to the CEO (Hwang and Kim (2009)). Our results deepen the understanding of the role of reputation in enhancing a director's monitoring incentives (Masulis and Mobbs (2014)). To our knowledge, no other study examines incentives arising from cartel prosecution and how these incentives affect directors' actions.

Finally, our findings are related to the nascent literature on the efficacy of whistle-blowing programs. Dyck et al. (2010) and Bowen et al. (2010) document that whistle-blowing by employees plays a key role on fraud detection and is mainly driven by monetary rather than reputational incentives. We contribute to this literature by providing evidence on the effect of director's reputational incentives on firms' participation in corporate leniency programs.

The remainder of the paper proceeds as follows. Section 2 provides background on cartel enforcement. Section 3 describes the sample and the key variables used in this study. We 
analyze stock market reactions to cartel discovery in Section 4. The consequences of cartel prosecution for individual directors are presented in Section 5. Section 6 presents our analysis of director behavior around cartel prosecution. Section 7 concludes.

\section{Background on Cartel Prosecution}

The first formal cartel investigations in the US took place following the Sherman Act of 1890. Subsequent legislation has shaped the role and scope of actions by antitrust authorities. $^{7}$ In Europe, antitrust regulatory efforts started in 1958 with the Treaty of Rome, which set the basis for the competition policy of the EU. Antitrust actions have increased dramatically in recent years both in the US and in the EU. A recent surge in cartel prosecution activity has been preceded by an increase in the penalties associated with price-fixing and the introduction of leniency programs.

Regarding penalties, the US introduced the Antitrust Criminal Penalty Enhancement and Reform Act (ACPERA) in 2004. ACPERA increased the maximum corporate fine to $\$ 100$ million, the maximum individual fine to $\$ 1$ million, and the maximum prison term to 10 years. In Europe, antitrust fines were substantially revised in 2006.

Leniency programs define rules for granting reductions in penalties to firms or individuals that step forward to report participation in cartel activities and provide active cooperation in investigations conducted by enforcement authorities. In the US, the Corporate Leniency Program was introduced in 1978 to grant full amnesty to the first informant firm. The program was amended in 1994 to grant amnesty to individuals, and in 1999 to decrease penalties in exchange for information about other cartels in which investigated firms were involved. Leniency programs were introduced in Europe in 1996.

The theoretical literature on antitrust action highlights the trade-offs faced by the regulation of cartel prosecution. Some authors suggest that leniency programs can be an effective cartel deterrence tool, as the possibility of applying for leniency exacerbates conflicts of interests amongst managers of colluding firms (see, e.g., Aubert et al. (2006) and Harrington (2008)). Others, however, argue that because firms can obtain lower fines from cooperation

\footnotetext{
${ }^{7}$ The relevant legislation includes the Clayton Act (1914), the Robinson-Patman Act (1936), and the Celler-Kefauver Act (1950).
} 
with antitrust prosecutors, the existence of a leniency program reduces the expected costs of cartel involvement (Motta and Polo (2003) and Spagnolo (2004)).

Theoretical work also proposes that corporate governance is likely to play a role in cartel activity since joining a cartel is decided at the very top of a firm's hierarchy. Prior studies posit that certain corporate governance structures and managerial compensation schemes may facilitate collusive agreements (see, e.g., Harrington (2006) and Buccirossi and Spagnolo (2008)). From an empirical perspective, however, the role of governance on cartel activity is understudied. Artiga González et al. (2013) document that cartel firms use financial reporting and corporate governance strategies to hide their fraudulent behavior. To our knowledge, no prior study empirically examines how the incentives of different firm officials shape the prosecution of cartel schemes.

\section{Data and Variable Construction}

Our analysis is based on data from the Private International Cartel (PIC) database. ${ }^{8}$ The PIC data contain information on the universe of private international cartels detected since 1990 (see Connor (2014) for a detailed description). The data include each firm's name, country of incorporation, the markets and locations where collusion took place, the duration of the collusive agreement, the fines imposed, and whether the firm was granted amnesty under a plea deal. PIC also contains information on the "key dates" of the prosecution process: 1) the date when a cartel investigation is first publicly revealed (the first notice date), and 2) the date on which penalties are publicly announced. Information on prosecution dates are collected from press releases of antitrust authorities, such as the US Department of Justice, the Canadian Competition Bureau, the European Commission, and other national authorities with active anti-cartel programs. First notice dates are also obtained from business newspapers, trade magazines, and news services.

We select firms headquartered in the US with non-missing Compustat and CRSP data. Because our tests require detailed data on board characteristics, we also impose that the

\footnotetext{
${ }^{8}$ The term "private" in the context of cartels is used to differentiate illegal price-fixing schemes from ("public") price agreements protected by government sovereignty or by international treaties, such as OPEC. The term "international" indicates that the cartel is formed by (1) at least one corporate participant with headquarters, residency, or nationality outside the jurisdiction of the investigating antitrust authority, or by (2) at least two members with different nationalities (cf. DOJ (2013)).
} 
firms are covered by Equilar. ${ }^{9}$ These requirements result in a sample of 191 American public firms involved in 199 cartels prosecuted by 41 antitrust authorities from 2002 to 2012. Some firms are prosecuted for more than one cartel and/or in different jurisdictions. Moreover, for a given firm-cartel-jurisdiction observation we consider both the first announcement of the prosecution and the announcement of the penalties imposed. Accordingly, the number of observations in our tests varies according to the level of analysis. In all, our sample includes 373 firm-cartel observations, 519 firm-year observations, 585 firm-cartel-jurisdiction observations, and a total of 1,028 announcements.

Table 1 presents descriptive statistics for the firms and cartels included in our sample. Panel A shows that those firms cover a wide range of industries with a relatively high representation of producers of chemicals and allied products, consumer nondurables, manufacturing, as well as financial firms.

\section{TABLE 1 ABOUT HERE}

Panel B presents statistics of the following characteristics of the sample firms: $M V$ is the firm's equity market value, $B M$ is the firm's book-to-market ratio, Past_Return is the firm's market-adjusted return, $R O A$ is the firm's return on assets, computed as operating income before depreciation scaled by total assets, Leverage is the leverage ratio of the firm, computed as total debt scaled by total assets, and Volatility is the market-adjusted stock return volatility of the firm. All of these proxies are measured using the most recent accounting and market data prior to the prosecution announcement.

Not surprisingly, cartel firms tend to be large. The mean (median) market capitalization of cartel firms is $\$ 43,574(10,774)$ million, while the mean (median) market capitalization of the firms in the CRSP-Compustat universe is $\$ 2,794$ (275) million. Panel B also shows that the cartel firms have relatively low book-to-market ratios and are comparatively more profitable, but not riskier than the typical firm in the CRSP-Compustat universe.

Panel B also presents statistics for several governance characteristics of the cartel firms. Independent_Directors is the number of independent directors scaled by the total number of directors. Chair_Insider equals one if the chair of the board also holds an executive position,

\footnotetext{
${ }^{9}$ The Equilar database provides board composition data collected from annual proxy filings (DEF 14A) with the SEC. The database covers a large number of firms starting from fiscal year 2001.
} 
and zero otherwise. Staggered equals one if the corporate directors have staggered terms, zero otherwise. Busy_Directors is the number of outside directors who serve simultaneously on at least two boards scaled by the total number of directors. Age_69 is the number of outside directors who are at least 69 years old scaled by the total number of directors. Indep_Director_Holdings is the number of shares held by outside directors scaled by the total number of shares outstanding. Institutional_Holdings is the number of shares owned by institutions scaled by the total number of shares. ${ }^{10}$

Summary statistics suggest that the sample firms have a high proportion of independent directors (more on this below). Panel B also suggests that sample firms are widely held; the mean (median) value of Institutional_Holdings is $72 \%$ (73\%). Although the CEO is the chairman of the board in $85 \%$ of the cases, the percentage of staggered boards (34\%) is lower than the typical firm in Equilar (51\%).

Panel C presents statistics on the characteristics of the 199 cartels in which the sample firms were involved. Number_Participants is the number of firms involved in the cartel. Duration is the number of years from the beginning to the end of the cartel. Cartel_Sales is the total revenues of the cartel firms during the collusive period (expressed in $\$$ million). Fines_Cartel is the total amount of monetary fines imposed on all of the firms that participate in a given cartel (in $\$$ million). Leniency_Cartel equals one if the cartel prosecution was prompted by a leniency application, and zero otherwise. For each cartel firm, Fines_Firm_Pct is the total fines imposed on the firm divided by the sum of fines imposed on all cartel firms. Recidivism is the number of times the firm has been prosecuted for involvement in prior cartels. We note three characteristics that warrant attention. First, the total volume of sales affected by these cartels is substantial ( $\$ 49.3$ billion). On average, firms receive substantial fines (\$67 million) for cartel involvement. Finally, about one third of the cartels we analyze $(32 \%)$ were uncovered through leniency applications. ${ }^{11}$ This last statistic reflects the importance of those programs in cartel prosecutions.

\footnotetext{
${ }^{10}$ Data on institutional ownership are collected from the Thomson-Reuters database of 13-F filings (CDA/Spectrum).

${ }^{11}$ Not every leniency applicant is present in our sample of cartel firms. For example, the applicant could be a private firm or a non-US firm that is not included in our sample because of data limitations. Also note that the jurisdiction statistics in Table 1, Panel C, do not add up to $100 \%$ because some cartels are prosecuted in several jurisdictions.
} 


\section{Independent Directors and the Market Reaction to Cartel Prosecution}

\subsection{Equity Returns}

Our first set of tests focuses on the stock market reaction to news about cartel prosecutions. If the stock market anticipates that independent directors will pursue actions that reduce the costs of prosecuting illicit activities, we expect to find a positive association between announcement returns and the percentage of independent directors at the time of the announcement.

We collect dates on antitrust authorities' announcements of investigations as well as convictions and other similar rulings. We gather these dates for each cartel allegation in which our sample firms are involved and for each jurisdiction in which the cartel is prosecuted. This results in a total of 1,028 prosecutory events.

We examine the association between announcement returns and the percentage of independent directors by estimating the following regression model:

$$
\begin{aligned}
\text { Abnormal_Return }_{i, t} & =\beta_{1} \text { Independent_Director }_{i, t-1}+\beta_{2} \text { Firm_Controls }_{i, t-1} \\
& +\beta_{3} \text { Governance_Controls }_{i, t-1}+\beta_{4} \text { Cartel_Controls }_{i, t-1}+\epsilon_{i, t},
\end{aligned}
$$

where $i$ indicates the firm, $t$ indicates the date of the announcement. Abnormal_Return is constructed as the market-adjusted return on the announcement date (expressed in per-

centage terms). Independent_Directors is the percentage of independent directors on the board. Eq. (1) includes controls for variables found by prior literature to be associated with the cross-section of stock returns and other firm characteristics. Firm_Controls includes Size, BM, and Past_Return, Leverage, ROA, and Volatility. We also add corporate governance measures that could be correlated with independent directors. Governance_Controls includes Staggered, Chair_Insider, Busy_Directors, Age_69, Indep_Director_Holdings, and Institutional_Holdings. All these independent variables are measured using the most recent disclosures of accounting and governance information prior to the announcement date. We also control for the cartel characteristics that could shape the stock market reaction to the 
prosecution announcement. Cartel_Controls includes Number_Participants, Duration, Cartel_Sales, Fines_Cartel, Fines_Firm_Pct, and Recidivism. Finally, we include jurisdiction-, year-, and industry-fixed effects to control for antitrust authorities' institutional characteristics, macroeconomic conditions, and industry characteristics. ${ }^{12}$

Table 2 presents the results of estimating Eq. (1) including: (1) the first announcement of each cartel prosecution in each jurisdiction (First Notices), and (2) all available cartel news dates, including announcements of sanctions (All Prosecution Announcements). The proportion of independent board members is positively associated with the announcement returns; the coefficient on Independent_Directors is positive and significant across all specifications. The magnitude of the univariate coefficient on Independent_Directors on the sample of first announcement dates (column (1)) is 5.65, which implies that one-standard deviation change in Independent_Directors (i.e., 15\%) is associated with an average difference of 84 basis points in daily returns on days containing news about cartel prosecution announcements. This is a significant figure since the unconditional average abnormal return in those days is -39 bps basis points.

\section{TABle 2 ABOUt HeRE}

\subsection{Robustness}

\subsubsection{Heckman Sample Selection}

One concern about our results is that our sample of prosecuted firms has not been randomly selected. Summary statistics show, for example, that the sample firms have a high proportion of independent directors, suggesting that observations in our sample might not be representative of the universe of firms.

We deal with this concern in two different ways. First, we compare the percentage of independent directors among our sample firms to that of comparable industry peers. For each sample firm, the corresponding industry peer is defined as the firm with the same 4-digit SIC code that is closest in size to the sample firm. As shown in Figure 2, our sample firms do not differ from comparable industry peers in terms of the empirical distribution of Independent_Directors. To test this inference more formally, we perform a Kolmogorov-Smirnov

\footnotetext{
${ }^{12}$ We apply a logarithmic transformation to the variables that are not defined as fractions and are not indicator variables, namely Volatility, Number_Participants, Duration, Cartel_Sales, and Fines_Cartel.
} 


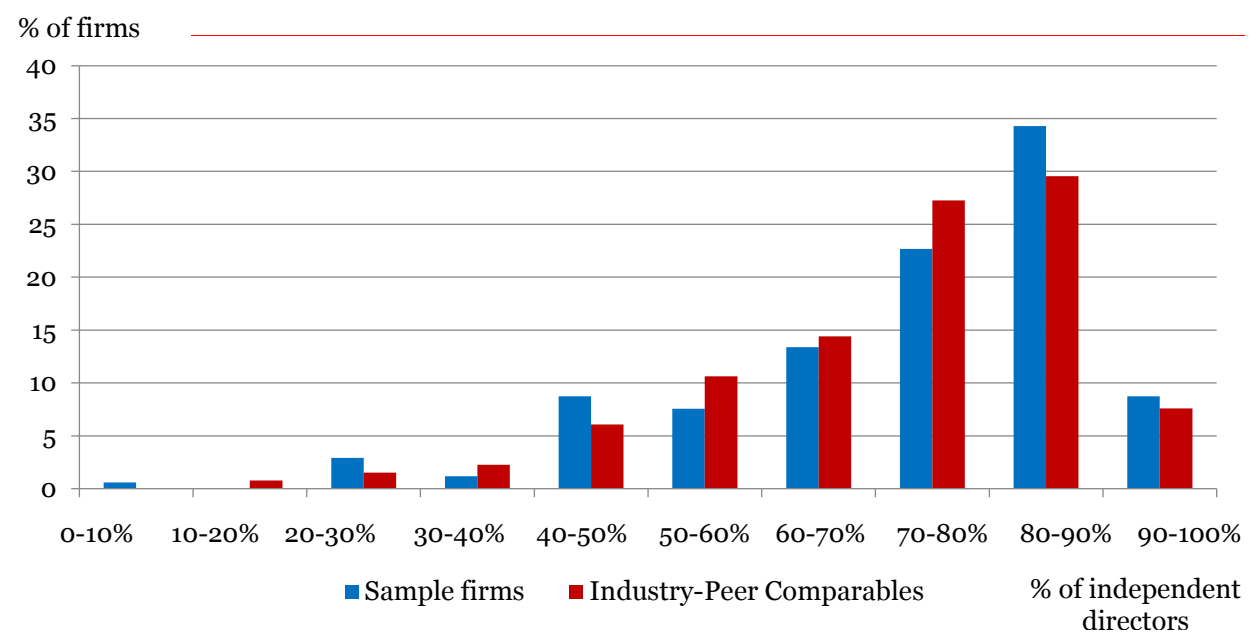

Figure 2. Board Independence. This figure plots data on the percentage of independent directors in sample and benchmark firms between 2002 and 2012. The vertical axis indicates percentage of firms. The horizontal axis indicates percentage of independent directors. Data on director independence comes from Equilar.

distribution test. The $p$-value of 0.189 shows that the two Independent_Directors samples are drawn from the same distribution.

We further examine whether sample-selection is likely to confound our results by estimating an alternative specification of Eq. (1) including a Heckman-correction term (Heckman (1979)). In the first stage of the Heckman model we include the determinants of the inclusion of a firm in the sample (i.e., the probability of cartel prosecution) as follows:

$$
\begin{aligned}
\text { Prosecution }_{i, t} & =\beta_{1} \text { Independent_Director }_{i, t-1}+\beta_{2} \text { Firm_Controls }_{i, t-1} \\
& +\beta_{3} \text { Governance_Controls }_{i, t-1}+\beta_{4} \text { Prosecution_Effort }_{i, t-1} \\
& +\beta_{5} \text { Collusion_Incentives }_{i, t-1}+\epsilon_{i, t},
\end{aligned}
$$

where $i$ indicates the firm, $t$ indicates the year of the prosecution. Prosecution equals 1 if firm $i$ is involved in a cartel detected in year $t$, and 0 otherwise. The control group of nonprosecuted firms is formed by all the firms in the CRSP-Compustat universe, resulting in a panel of 32,592 observations. Independent_Directors is the percentage of independent directors on the board. Firm_Controls and Governance_Controls are previously defined vectors of variables measured at the start of the year. Prosecution_Effort includes two measures of regulatory effort to prosecute price-fixing cartels. The first is Punishment_Severity, which is the 
logarithm of the average fine imposed by the DOJ in that year. The second, Budget_Increase, is the inflation-adjusted increase in the budget of the Antitrust Division of the DOJ.

Following previous research (e.g., Shapiro (1989) and Levenstein and Suslow (2006)), we include in Eq. (2) measures of conditions that lead to engaging in (and sustaining) price fixing behavior (Collusion_Incentives). Herfindahl is the Herfindahl index of the industry. Innovation is the industry average of the R\&D expenses scaled by total assets. Barriers_to_Entry is the industry average of the PP\&E expenses scaled by total assets. Number_Competitors is the number of firms in the industry. Cost_Asymmetry is the industry standard deviation of cost of goods sold (COGS) scaled by total assets. Market_Power is the industry average of the selling margin, computed as (sales revenues - COGS) / sales revenues. Heterogeneity is the industry standard deviation of the selling margin, computed as (sales revenues COGS) / sales revenues. We include controls for demand conditions that favor collusion (cf., Rotemberg and Saloner (1986)). Demand_Growth is the percentage increase of industry sales. Demand_Volatility is the standard deviation of industry sales as percentage of total assets. Demand_Elasticity is the correlation between percentage changes in industry sales and percentage changes in the sum of sales across all Compustat firms. Finally, because prior literature suggests that multi-market contacts among firms could favor collusion (e.g., Bernheim and Whinston (1990)), we also include a measure of the degree of business diversification of the company. Diversification is defined as the number of business segments in which the company operates.

In the second stage of the Heckman model, the dependent variable Abnormal_Return is computed for each firm-cartel observation as the average market-adjusted return to prosecution announcements. In the first set of columns (First Notices), Abnormal_Return is computed as the average market-adjusted return on the first prosecution announcement across all jurisdictions in which the cartel was prosecuted. In the second set of columns (All Prosecution Announcements), Abnormal_Return is computed including all prosecution announcements related to the cartel (i.e., also including announcements of sanctions and terminations). The second stage of the model includes the following controls: Size, BM, and Past_Return.

Table 3 presents the results. The first-stage estimates imply that there is no association between Independent_Directors and the probability of undergoing cartel prosecution. This result is consistent with the descriptive analysis in Figure 2, in which there is no observable 
difference in the percentage of independent directors between our sample firms and their matched industry-peers.

The estimations also show that cartel involvement is associated with corporate governance characteristics. For example, firms in which the CEO is also the chairman of the board are more likely to be involved in cartel prosecutions. The positive and significant coefficient on Budget_Increase suggests that increases in prosecution efforts lead to a higher probability of prosecution. Regarding the determinants of collusive behavior, we find that the probability of cartel involvement is higher among firms producing products with a higher degree of innovation, firms with less elastic demand, firms operating in markets with a smaller number of competitors, and firms with presence in a higher number of markets.

\section{TABLE 3 ABOUT HERE}

More importantly, the second stage of the Heckman model shows that the inverse Mills ratio is highly significant. The sample-selection correction, however, does not subsume the economic or statistical significance of the coefficient on Independent_Directors.

\subsubsection{Independently Appointed Directors}

Managers often exert significant influence on the nomination of board members. Accordingly, one can argue that the distribution of independent directors in our sample could be associated with factors that also influence the market reactions to cartel prosecutions. In this section, we explore the sensitivity of our results to the potentially endogenous nature of board independence by conducting an in-depth analysis of the sources of cross-sectional variation in our key independent variable, Independent_Directors.

We analyze the circumstances around the appointment of each one of the directors serving on the prosecuted board at the time of prosecution. Notably, director appointments usually occur several years prior to the cartel prosecution, under circumstances not necessarily related to the conditions leading to cartel formation and prosecution. Those appointments are also motivated by several different regulatory-, legal-, market-driven factors; factors that are outside of managers' control. In turn, we identify appointments in which the board change is less likely to have been driven by management's influence. 
We code each independent director according to whether the appointment occurred under the following circumstances: (1) Appointed at the passage of $S O X$ equals one if the appointment of the independent director occurred in 2002 (year of the passage of The Sarbanes Oxley Act) and if the audit committee was not fully independent at the start of 2001, and zero otherwise; ${ }^{13}$ (2) Appointed before the CEO's tenure equals one if the appointment of the independent director occurred before the appointment of the current CEO, and zero otherwise; (3) Appointed in difficult times equals one if the industry returns over the 12 months prior to the appointment of the independent director are negative, and zero otherwise; (4) Appointed after class action suits equals one if the firm was subject to shareholder litigation during the 12 months prior to the appointment of the independent director, and zero otherwise; ${ }^{14}$ and (5) Appointed under voting concerns equals one if directors experienced a decrease of more than $1 \%$ in voting support at the prior election or if ISS issued a "withhold" recommendation for any of the directors, and zero otherwise.

We re-estimate Eq. (1) replacing Independent_Directors with Independent_Appointment, which is computed as the number of independent directors appointed under the circumstances listed above divided by the total number of directors. For example, if there are 7 independent directors out of 10 board members, and 4 of the independent directors were appointed under any of the five circumstances described above, Independent_Directors equals 0.7 and Independent_Appointment, equals 0.4. Thus, Independent_Appointment captures the proportion of directors that were independent at the time of prosecution, yet were appointed for reasons likely unrelated to CEOs' influence or interests.

Table 4 presents results for three alternative definitions of Independent_Appointment. Specifically, we define Independent_Appointment, based on the number of directors appointed under at least one, two, or three of the five previously mentioned circumstances. ${ }^{15}$ The coefficient on Independent_Appointment, is consistently positive and statistically significant using all three definitions. For robustness, we repeat the analysis replacing $I$ dependent_Appointment, with its complementary measure, namely Independent_Directors -

\footnotetext{
${ }^{13}$ Prior research (e.g., Linck et al. (2009) and Duchin et al. (2010)) has used similar strategies to empirically identify the effect of independent directors' actions on firm value.

${ }^{14}$ We identify whether the firm was subject to litigation in that period using data on press releases from the CapitalIQ Key Developments database.

${ }^{15}$ The set of firms whose independent directors were appointed under the combination of four or all five of the circumstances listed is nearly empty.
} 
Independent_Appointment. In contrast with the results in Table 4, the coefficient on this complementary measure (which captures the percentage of independent directors more likely to be appointed under managers' influence) is generally not statistically significant. This evidence suggests that the directors that play a role in cartel prosecution are less likely to have been appointed under the scandal-laden CEOs' influence. To the extent that this analysis is akin to an instrumental variables approach (the "instrument" being the circumstances suggesting low managers' influence at the appointment), the results in Table 4 help mitigate selection concerns related to Independent_Directors.

\section{TABLE 4 ABOUT HERE}

\subsubsection{Effect of Prosecutions on Peer Firms}

It is important to characterize our results on the role of independent directors in prosecutory events and the setting we study is particularly useful. A cartel investigation is seen as a shock that increases the probability of prosecution of other firms in the industry (see Hammond (2009)). We exploit this pattern to explore whether the market reaction to an increase in the probability of prosecution also varies with the fraction of independent directors in the unprosecuted firms.

For each firm prosecuted for involvement in a given cartel, we identify a sample of unprosecuted industry peers using the text-based approach of Hoberg and Phillips (2010). For robustness, we repeat the analysis defining as peers the firms in the same 4-digit SIC code of the prosecuted firm. Using these alternative samples of unprosecuted peers we estimate the following model:

$$
\begin{aligned}
\text { Abnormal_Return }_{j, i, t} & =\beta_{1} E\left[\text { Prosecution }_{j, t-1}+\beta_{2} \text { Independent_Directors }_{j, t-1}+\right. \\
& +\beta_{3} E\left[\text { Prosecution }_{j, t-1} * \text { Independent_Director }_{j, t-1}+\beta_{4} \text { Size }_{j, t-1}\right. \\
& +\beta_{5} \text { B }_{j, t-1}+\beta_{6} \text { Past_Return }_{j, t-1}+\epsilon_{j, i, t}
\end{aligned}
$$

where $j$ indicates the unprosecuted peer, $i$ indicates the prosecuted firm, $t$ indicates the date of the announcement. For each unprosecuted peer, the dependent variable Abnormal_Return is the market-adjusted return on the announcement date of a cartel prosecution in a peer 
firm (expressed as a percentage). Independent_Directors is the percentage of independent directors on the board. For each unprosecuted firm, we use two measures of the probability of potential prosecution, E[Prosecution]. Our first measure equals one if the firm is prosecuted in the future (i.e., if the firm appears in the PIC dataset because of later prosecutions). Our second measure is computed as the fitted value of the logit model in Eq. (2); that is, the model we use in the Heckman-correction test to explain the probability of cartel prosecution.

Table 5 presents the results from estimating Eq. (3). The coefficient on E[Prosecution] suggests that returns of unprosecuted firms that are likely to be the target of cartel investigations are significantly negative upon the announcement of a cartel prosecution. More importantly, the positive and significant coefficient on the interaction between E[Prosecution] and Independent_Directors suggests that, among unprosecuted firms, the expected costs of prosecution are lower for firms with a higher percentage of independent directors.

\section{TABLE 5 ABOUT HERE}

Results from Table 5 suggest that inferences about the role of independent directors in prosecuted firms may be extended to unprosecuted firms that are likely to be prosecuted. This suggests that the negative externalities from cartel indictments may be contained when comparable, peer firms have more independent directors in the boards.

\section{$5 \quad$ Independent Directors' Incentives and Losses around Cartel Prosecution}

The results in the prior section suggest that the presence of independent directors mitigates the negative returns associated with cartel prosecution. In this section we examine whether the returns pattern we document is driven by directors' incentives and costs associated with public prosecutions. 


\subsection{Independent Directors' Incentives}

We start by analyzing whether the association between Abnormal_Return and Independent_Directors is stronger among directors with more powerful incentives to act around cartel prosecution. We construct two variables to gauge those incentives. The first gauges independent directors' human capital (or reputation), specifically their portfolio of directorships in other firms. We define Other_Boards as the value-weighted average of the number of outside boards in which a firm's independent directors serve. ${ }^{16}$ If cartel prosecution has spillover effects onto other boards in which directors serve, directors with a higher number of outside directorships are exposed to a larger downside from cartel prosecution. As such, we expect the relation between Abnormal_Return and Independent_Directors to be stronger among firms with higher values of Other_Boards.

Our second measure is based on directors' monetary incentives. Stock_Options measures the percentage of stock options in the director's equity holdings in the prosecuted firm. As shown in prior literature (Guay (1999)), stock options provide for risk-taking incentives by introducing convexity in compensation schemes. Notably, it has been shown that fraud is one of the risky strategies that firms follow to maximize the value of stock options (Armstrong et al. (2013)). Directors with a lower proportion of options have a less convex payoff function (i.e., less powerful risk-taking incentives) than directors with larger option holdings. As such, we expect the relation between Abnormal_Return and Independent_Directors to be stronger among firms with lower values of Stock_Options.

Table 6 first presents the results from estimating Eq. (1) partitioning the sample into tertiles (based on our two measures of directors' incentives). In columns (1) and (2), the positive coefficient on Independent_Directors is larger for the subsample of firms in the top tertile of Other_Boards. The difference in the magnitude of the coefficients on Independent_Directors in the subsamples of firms in the top and bottom tertiles is statistically significant $(p$-value $<0.01)$. This evidence suggests that the positive association between announcement returns and Independent_Directors is concentrated among firms in which directors hold a larger number of outside directorships and thus a potentially larger downside from cartel prosecution. Analogously, columns (3) and (4) show that the positive associa-

\footnotetext{
${ }^{16}$ We value-weight the average of outside directorships because reputation concerns vary significantly across boards depending on board prestige (proxied by the market value of other firms in which the directors serve).
} 
tion between Independent_Directors and abnormal returns is concentrated among firms in which independent directors hold relatively fewer stock options. Similar to the prior test, the difference in the coefficients on Independent_Directors in the subsamples of firms in the top and bottom tertiles of Stock_Options is statistically significant ( $p$-value $<0.01)$.

\section{TABLE 6 ABOUT HERE}

Taken together, the results in Table 6 suggest that the value losses stemming from cartel prosecution are less pronounced when the downside potential of directors' objective function is larger. This evidence is consistent with the notion that the return patterns documented in Section 4 are associated with directors' incentives.

\subsection{Independent Directors' Losses}

We substantiate our argument about independent directors' incentives to act around cartel prosecution by studying whether those directors observe sizable negative consequences arising from their involvement with cartels. Finding that independent directors bear significant personal costs from such public indictments would suggest that may take actions to avoid or mitigate those costs. Understanding this dynamic is particularly useful for prosecutory authorities.

\subsubsection{Loss of Directorships}

We study whether independent directors lose board seats after news about the cartel scandal emerge. Although board directors are rarely dismissed, they are often pressured to leave their seats after firm misconduct. Indeed, previous literature documents that directors are more likely to leave their seats after news of financial irregularities (e.g., Srinavasan (2005), Fich and Shivdasani (2007), and Ertimur et al. (2012)).

We refer to the directors serving on the board of our sample of prosecuted firms as "cartel directors". For each cartel director, we collect data on whether the director departs from his/her directorships in year $t+1$ ( $t$ being the year in which there is a prosecution announcement). We find that cartel directors experience significant turnover following prosecution. The departure frequency is $9.3 \%$ from prosecuted directorships (to which we refer as "cartel 
directorships") and 11.3\% from unprosecuted directorships ("non-cartel directorships"). Because we are interested in validating our first measure of directors' incentives, Other_Boards, we focus on the latter group, namely cartel directors' non-cartel directorships (positions in firms that are not indicted by antitrust authorities). There are 4,453 director-firm-year observations in this group.

To provide a benchmark for cartel directors' departure rate from non-cartel directorships, we compare director departure frequency in our "treatment" group to director departure frequency in five control groups. First, we compare the treatment group to all directorfirm-year observations with non-missing data in BoardEx in which neither the firm nor the director are involved in cartel prosecutions during our sample period.

Second, to avoid imbalance in the number of observations between the treatment and the control groups, we compare the treatment group to 1,000 director-firm pairs randomly drawn from the BoardEx universe. In each iteration, and for each director-firm observation in the treatment group, we randomly select an unprosecuted director-firm observation in the same year and industry as the treatment observation.

Third, we compare the treatment group to a sample of director-firm pairs from the universe of public firms in BoardEx using propensity-score matching. Specifically, for each director-firm observation in the treatment group, we use Derigs' (1988) propensity score matching algorithm to find the observation in the BoardEx universe of unprosecuted directorfirm observations that is closest in terms of firm characteristics (the variables included in Firm_Controls) and director characteristics. ${ }^{17}$ We add two director characteristics that are likely to be associated with the probability of directorship departure. Because older directors are more likely to retire, we include the age of the director in a given year (Age). We also include the director's total number of directorships in a given year (NBoards). This variable is a proxy for the director's current reputation (see Masulis and Mobbs (2014)) and is included to control for potential variation in the personal cost of departing from a directorship.

Fourth, to control for the potentially confounding effect of unobserved director characteristics, we compare the treatment group to cartel directors' directorships in "non-prosecution years" (i.e., years with no prosecution announcement). That is, this control group includes the same directors as the treatment group (cartel directors), but different directorship-year

\footnotetext{
${ }^{17}$ We restrict the pool of potential matches to firms in the same years as the treatment firms.
} 
observations for those directors; akin to a "within-director" fixed effect model.

Fifth, to control for confounding effects of unobserved firm characteristics, we compare the treatment group to cartel directors' codirectors in Tables 7-8 we have Codirectors in non-cartel directorships. To wit, this control group includes directors serving on the same unprosecuted boards as cartel directors in prosecution years (i.e., years in which there is prosecution announcement at one of the cartel directors' directorships). As such, the treatment group and this control group include the same firms, but different directors.

Table 7 presents the results of testing the difference in Departure_NonCartel (defined as one if the director departs from that directorship in year $t+1$, and zero otherwise) between the treatment group and each of the five control groups just described. As shown in Table 7, differences in departure rates are statistically significant in all five tests. The magnitude of the difference varies from $1 \%$ to $4 \%$ across control groups. These magnitudes are significant considering that the average departure rate in the BoardEx universe is $7.9 \%$.

\section{TABLE 7 ABOUT HERE}

To fully describe the process of departure of independent directors from indicted firms, we conduct a survival analysis of the previously defined treatment and control groups. Because prior literature has shown that officer turnover subsequent to negative corporate events often occurs over a 3-year horizon (e.g., Srinavasan (2005), Fich and Shivdasani (2007), and Karpoff et al. (2008)), the analysis is performed using departure announcement dates over the 36 months following the announcement of cartel prosecution. We measure the timing of the director departure using departure announcement data from BoardEx. To compute the survival function after prosecution for the control group, we attach to each control observation the prosecution announcement date of its corresponding pair in the treatment group. This requires a unique date correspondence for each control observation and thus restricts the analysis to three of the previously defined control groups: random pairs, propensity score matching, and codirectors in unprosecuted directorships.

Figure 3 plots the survival functions of the treatment group (directors involved in cartel prosecutions) and the three previously described control groups. The survival function of the treatment group (in blue) exhibits a steeper downward trend than those of the other 


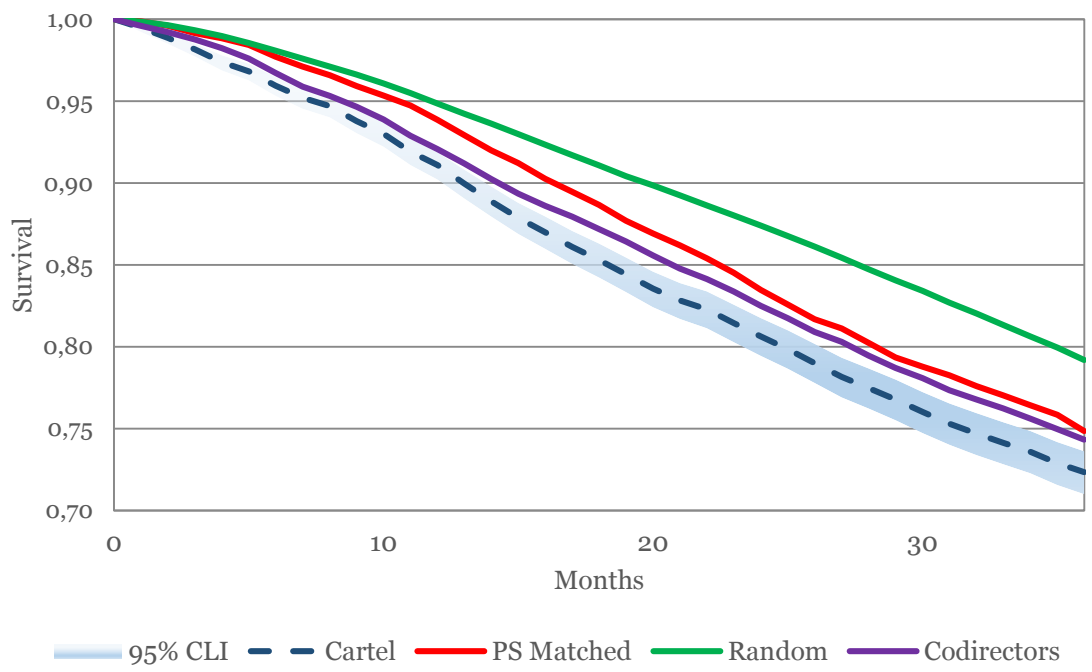

Figure 3. Job Survival Function of Directors Involved in Cartel Prosecution. This figure presents the job survival rates for directors serving on boards of firms prosecuted for cartel involvement and three control groups of directors. "Cartel" (in blue) refers to the survival function of directors involved in cartel prosecutions at unprosecuted directorships. 95\% confidence limit intervals (CLI) are shaded in blue. "Matched" (in red) refers to the survival function of a matched sample of directors not involved in cartel prosecution. "Random" (in green) refers to the average survival function of 1,000 random samples of directors in the same year and industry that are not involved in cartel prosecution. "Codirectors" (in violet) refers to the survival function of directors not involved in cartel prosecution serving on the same unprosecuted directorships as cartel directors.

three groups, suggesting that cartel directors experience a significantly lower probability of survival at unprosecuted directorships than control directors. The magnitude of the differences between the survival rates of the treatment and control groups are consistent with our results in previous tests (the differences vary from approximately $1 \%$ to $4 \%$ over one year after the prosecution announcement).

Taken together, the results in Table 7 and Figure 3 imply that independent directors involved in cartel investigations are more likely to lose directorships after prosecution announcements. This evidence supports the hypothesis that those directors suffer significant personal costs from cartel prosecution, and extends prior findings on the reputational consequences of other types of corporate misbehavior, such as securities fraud (e.g., Srinavasan (2005) and Fich and Shivdasani (2007)). 


\subsubsection{Loss of Voting Support in Director Elections}

We investigate whether cartel directors lose voting support in director elections following cartel prosecution announcements. This analysis is informative because a lower voting support across directors' portfolio of directorships would suggest that these professionals face reputational penalties from cartel involvement even when those reputational penalties might not be strong enough to force resignations or cause them to lose future re-election bids. Indeed, research shows that losses in voting support have important consequences for directors' future professional opportunities (Ertimur et al. (2012)).

We analyze changes in voting support after cartel prosecution announcements by collecting information on shareholder voting on director elections from the ISS Voting Analytics database. ${ }^{18}$ The database includes voting data since 2003 and covers companies included in the Russell 3000. Similar to prior tests, we contrast changes in voting support between the treatment group of cartel directors' unprosecuted directorships against the five control groups defined in the last section. For each director-firm-year observation, we compute $\Delta$ Support_NonCartel $_{i, j, t}$ as the percentage of "For" votes for director $i$ at firm $j$ at the annual meeting of year $t$ minus the percentage of "For" votes for director $i$ at firm $j$ at the annual meeting of year $t-1$. The mean value of $\Delta$ Support_NonCartel in the treatment group is $-1 \%$, implying that cartel directors lose voting support after cartel prosecution news.

Table 8 presents the results. The difference in the mean value of $\Delta$ Support_NonCartel between the two groups varies from 0.80 to $0.92 \%$, being lower among the observations in the treatment group. The standard deviation of $\Delta$ Support_NonCartel is $8 \%$, implying that a non-trivial percentage of cartel directors experience a considerable increase in withheld votes. ${ }^{19}$ These results confirm that, after cartel prosecution news, directors of cartel firms lose voting support across their portfolio of directorships.

\section{TABLE 8 ABOUT HERE}

\footnotetext{
${ }^{18}$ The ISS database compiles shareholder votes for all agenda items at a firm's shareholder meetings, including director elections. The database provides the identity of the companies holding elections, the shareholder meeting date, the agenda item descriptions, the number of "For", "Against", "Abstain", "Withhold" and "Do Not Vote" votes of institutional owners.

${ }^{19}$ To interpret the magnitude of $\Delta$ Support_NonCartel it is important to consider that the mean (median) voting support at director elections in the ISS Voting Analytics database is $94.8 \%$ (97.6\%). The $25^{\text {th }}$ percentile is $94.5 \%$, suggesting that an $8 \%$ decrease in support would place the director in the left tail of the distribution of voting support.
} 
In all, the evidence in Tables 7 and 8 suggests that independent directors are disciplined by the market following news of their involvement with cartels. This happens regardless of whether they are held personally accountable for illicit behaviors by antitrust authorities. The findings of this section suggest that, in addition to corporate fines and individual criminal and civil sanctions, there are sizable individual, market-based penalties stemming from involvement with cartels. They imply that independent directors may have incentives to aid antitrust authorities and corporate investors in correcting wrongdoing. We examine these hypotheses in turn.

\section{Directors' Actions around Cartel Prosecution: Ex- Ante and Ex-Post Behaviors}

\subsection{Leniency Applications}

One important action directors can take to mitigate the costs of cartel prosecution is to encourage the firm to cooperate with antitrust authorities by applying for leniency. Leniency programs grant amnesty regarding criminal penalties and substantially reduce the exposure to civil damages claims brought by injured private parties. ${ }^{20}$ Importantly, leniency applications may reduce reputational damage as the market interpret cooperation with authorities as directors fulfilling their monitoring role.

To test the association between the proportion of independent directors and the probability of applying for leniency, we collect data on corporate leniency applications from the PIC database. ${ }^{21}$ Because leniency applications are jurisdiction-specific, we include all the jurisdictions in which each sample firm is prosecuted for a given cartel and estimate the

\footnotetext{
${ }^{20}$ Leniency programs have been described by legal scholars as "the cornerstone of the Antitrust Divisions cartel enforcement regime because they create powerful incentives for self-reporting by wrongdoers that can have a significant destabilizing effect on a conspiracy" (Varney (2013)).

${ }^{21}$ Although the DOJ does not publicly disclose the identity of leniency applicants, this information is publicly available because its disclosure is required by courts in connection with litigation (Connor (2009)).
} 
following regression model: ${ }^{22}$

$$
\begin{aligned}
\text { Leniency }_{i, l, t} & =\beta_{1} \text { Independent_Director }_{i, t-1}+\beta_{2} \text { Firm_Controls }_{i, t-1} \\
& +\beta_{3} \text { Governance_Controls }_{i, t-1}+\beta_{4} \text { Cartel_Controls }_{i, t-1}+\epsilon_{i, l, t},
\end{aligned}
$$

where $i$ indicates the firm, $l$ indicates the jurisdiction, $t$ indicates the year of the prosecution. For each cartel and jurisdiction in which the firm is prosecuted, the dependent variable Leniency equals one if the company applies for leniency, and zero otherwise. Leniency equals one in 53 cases of the 579 jurisdiction-specific prosecutions. Eq. (4) also includes the three sets of control variables used in our prior tests; i.e., Firm_Controls, Governance_Controls, and Cartel_Controls.

Table 9 presents results from estimating Eq. (4). The coefficient for Independent_Directors is positive and significant across the different model specifications. The marginal effect of Independent_Directors in column (1) is 0.15 , implying that an increase of one standard deviation in Independent_Directors is associated with a $2.2 \%$ increase in the probability of applying for leniency. These results are consistent with the notion that independent directors favor cooperation with antitrust authorities as an attempt to mitigate personal costs associated with cartel prosecution. This is an important finding considering the increasing emphasis placed on leniency programs by proposed antitrust regulation.

\section{TABLE 9 ABOUT HERE}

\subsection{CEO Turnover Following Cartel Prosecutions}

The threat of incurring personal costs from cartel prosecution could also induce independent directors to take actions that enhance their reputation as monitors committed to punishing fraudulent behavior. An especially important disciplinary action the board can take is to replace the $\mathrm{CEO}$ of the prosecuted firm. Accordingly, we test whether firms with a higher proportion of independent directors are more likely to replace their CEO after cartel prosecutions. To perform this test, we collect data on CEO departures in the years in which there is

\footnotetext{
${ }^{22}$ Estimating equation (4) using logit and probit models results in identical inferences.
} 
news of cartel prosecution for our sample firms and estimate the following regression model: ${ }^{23}$

$$
\begin{aligned}
\text { CEO_Turnover }_{i, t} & =\beta_{1} \text { Independent_Director }_{i, t-1}+\beta_{2} \text { Firm_Controls }_{i, t-1} \\
& +\beta_{3} \text { Governance_Controls }_{i, t-1}+\beta_{4} \text { Cartel_Controls }_{i, t-1}+\epsilon_{i, t},
\end{aligned}
$$

where $i$ indicates the firm, $t$ indicates the month-year of the prosecution. For each firm $i$ being prosecuted in year $t, C E O_{-}$Turnover equals one if the CEO leaves the firm within the 12 months after the first news of cartel prosecution in month $t$, and zero otherwise.

The results from Table 10 show a positive association between Independent_Directors and CEO_Turnover. The coefficient on Independent_Directors is positive and statistically different from zero in all specifications. The coefficient of Independent_Directors in column (1) is 0.17 , implying that an increase of one standard deviation in Independent_Directors (i.e., 0.15 ) is associated with a $2.6 \%$ increase in the probability of CEO turnover. Our findings are consistent with the idea that independent directors replace the CEO after cartel detection in an effort to enhance their reputations as monitors.

\section{TABLE 10 ABOUT HERE}

\section{Conclusions}

Price-fixing schemes cost billions of dollars to the general public each year and antitrust authorities consider ways to address this problem. In this context, our paper sheds light on the role firm insiders can play in cartel detection and prosecutions. We do so by looking at the incentives and actions of a particular class of professionals in the modern corporation: independent directors.

We start by analyzing the stock market reaction to news of cartel indictments and other antitrust actions. We find that firms with a higher proportion of independent directors serving on their boards exhibit less negative abnormal returns. We also find that this association is stronger among firms in which directors hold more outside directorships and receive less option-based compensation. That is, our results are stronger in cases in which directors have

\footnotetext{
${ }^{23}$ Estimating equation (5) using logit and probit models results in identical inferences.
} 
less incentives to participate in corporate misconduct.

We explore whether potential reputational losses at outside directorships provide incentives for directors to deviate from price-fixing schemes by examining the ex-post effect of cartel prosecution on those directors' unprosecuted directorships. We find that directors of prosecuted firms lose board positions and voting support across their portfolio of outside directorships.

To better understand the association between cartel-busting news announcement returns and the proportion of independent directors, we look at directors' actions around cartel prosecution. We find that, ex-ante, firms with a higher proportion of independent directors are more likely to apply for leniency. Moreover, after news of cartel prosecution, there is a higher frequency of CEO turnover among firms with a higher proportion of independent directors.

Our results are consistent with the notion that outside directors' incentives can play a central role in cartel prosecution efforts. The analysis we present contributes to the regulatory debate on antitrust policies by providing evidence on the effect of market sanctions to individuals involved in price-fixing schemes. We believe the results of our study are relevant to regulators designing and enforcing antitrust policies and to market participants seeking to understand the role of corporate governance and antitrust regulation on firm value and behavior. 


\section{References}

Agrawal, A., Jaffe, J., Karpoff, J., 1999. "Management turnover and governance changes following the revelation of fraud." Journal of Law and Economics 42: 309-342.

Agrawal, A., Chen, M., 2011. "Boardroom brawls: An empirical analysis of disputes involving directors." Working paper.

Armstrong, C., Larcker, D., Ormazabal, G., Taylor, D., 2013. "The relation between equity incentives and misreporting: The role of risk-taking incentives." Journal of Financial Economics 109: 327-350.

Artiga González, T., Schmid, M., Yermack, D., 2013. "Smokescreen: How managers behave when they have something to hide." NBER Working Paper No. 18886.

Aubert, C., Kovacic, W., Rey, P., 2006. "The impact of leniency programs on cartels." International Journal of Industrial Organization 6: 1241-1266.

Bernheim, B.,Whinston, M., 1990. "Multimarket contact and collusive behaviour." Rand Journal of Economics 21: 1-26.

Bowen, R., Call, A. C., Rajgopal, S., 2010. "Whistle-blowing: Target firm characteristics and economic consequences." The Accounting Review 85: 1239-1271.

Brochet, F., Srinivasan, S., 2014. "Accountability of independent directors: Evidence from firms subject to securities litigation." Journal of Financial Economics 111: 430-449.

Buccirossi, P., Spagnolo, G., 2008. "Corporate governance and collusive behavior." CEPR Discussion Paper 6349.

Connor, J., Bolotova, Y., 2006. "Cartel overcharges: Survey and meta-analysis." International Journal of Industrial Organization 24: 1109-1137.

Connor, J., 2009. "Cartel amnesties granted: Worldwide whistleblowers." Working paper, Purdue University.

Connor, J., 2014. "The Private International Cartels (PIC) Data Set: Guide and summary statistics, 1990-2013." http://papers.ssrn.com/sol3/papers.cfm?abstract_id=2478271

Derigs, U., 1988. "Solving non-bipartite matching problems via shortest path techniques." Annals of Operations Research 13: 225-261.

DOJ, 2013. "Antitrust division manual." Fourth edition. http://www.justice.gov/atr/public/ divisionmanual/

Duchin, R., Matsusaka, J., Ozbas, O., 2010. "When are outside directors effective?" Journal of Financial Economics 96: 195-214.

Dyck, A., Morse, A., Zingales, L., 2010. "Who blows the whistle on corporate fraud?" Journal of Finance 65: 2213-2253. 
Ertimur, Y., Ferri, F., Maber. D., 2012. "Reputation penalties for poor monitoring of executive pay: Evidence from option backdating." Journal of Financial Economics 104: $118-144$.

Fich, E., Shivdasani, A., 2006. "Are busy boards effective monitors?" Journal of Finance 61: 689-724.

Fich, E., Shivdasani, A., 2007. "Financial fraud, director reputation, and shareholder wealth." Journal of Financial Economics 86: 306-336.

Guay, W., 1999. "The sensitivity of CEO wealth to equity risk: An analysis of the magnitude and determinants." Journal of Financial Economics 53: 43-71.

Hammond, S., 2009. "Cornerstones of an effective leniency program." Presented at the Chilean Competition Day. Santiago, Chile.

Harrington, J., 2006. "How do cartels operate?" Foundations and trends in microeconomics. Now Publishers, Hanover, MA.

Harrington, J., 2008. "Optimal corporate leniency programs." Journal of Industrial Economics 56: 215-246.

Heckman, J., 1979. "Sample selection bias as specification error." Econometrica 47: 153161.

Hermalin, B., Weisbach, M., 2003. "Boards of directors as an endogenously determined institution: A survey of the economic evidence." Economic Policy Review 9: 7-26.

Hoberg, G., Phillips, G., 2010. "Product market synergies and competition in mergers and acquisitions: A text-based analysis." Review of Financial Studies 23: 3773-3811.

Hwang, B., Kim, S., 2009. "It pays to have friends." Journal of Financial Economics 93: $138-158$.

Karpoff, J. M., Lee, D. S., and Martin, G.S., 2008. "The Consequences to Managers for Financial Misrepresentation." Journal of Financial Economics 88: 193-215

Levenstein, M., Suslow V., 2006. "What determines cartel success?" Journal of Economic Literature 44: 43-95.

Linck, J., Netter, J., Yang, T.,. 2009. "Effects and unintended consequences of the Sarbanes-Oxley Act on corporate boards." Review of Financial Studies 22:3287-328.

Masulis, R., Mobbs, S., 2014. "Independent director incentives: Where do talented directors spend their limited time and energy?" Journal of Financial Economics 111: 406-429.

Motta, M., Polo, M., 2003. "Leniency programs and cartel prosecution." International Journal of Industrial Organization 21: 347-379.

Rotemberg, J., Saloner, G., 1986. "A supergame-theoretic model of business cycles and price wars during booms." American Economic Review 76:390-407. 
Shapiro, C. 1989. "Theories of oligopoly behavior." In R. Schmalensee and R. Willig, eds., Handbook of Industrial Organization. New York: Elsevier Science Publishers: 330-414.

Spagnolo, G., 2004. "Divide et impera: Optimal leniency programs." CEPR Discussion Paper 4840.

Varney, C., 2013. "The cartels and leniency review." Ed. Law Business Research.

Yermack, D., 1996. "Higher market valuation of companies with a small board of directors." Journal of Financial Economics 40: 185-212.

Yermack, D., 2004. "Remuneration, retention, and reputation incentives for outside directors." Journal of Finance 59: 2281-2308. 


\section{Appendix A Variable Definitions}

\section{Firm Controls:}

$M V$ : Equity market value (in million dollars) of the firm

Size: Natural logarithm of $M V$

$B M$ : Book-to-market ratio. Book value of equity scaled by $M V$

Leverage: Total liabilities divided by total assets

Past_Return: Stock return compounded over the fiscal year

ROA: Return on assets (operating income scaled by total assets)

Volatility: Stock return volatility, computed as the standard deviation of daily returns over 365 days prior to fiscal year end

\section{Governance Controls:}

Independent_Directors: Percentage of independent directors on the board

Chair_Insider: Indicator variable that equals one if the chair of the board also holds an executive position, and zero otherwise

Staggered: Indicator variable that equals one if the corporate directors have staggered terms and zero otherwise

Busy_Directors: Number of outside directors who serve simultaneously on at least two boards scaled by the total number of directors

Age_69: Number of outside directors who are at least 69 years old scaled by the total number of directors

Indep_Director_Holdings: Number of shares held by outside directors scaled by the total number of shares outstanding

Institutional_Holdings: Number of shares owned by institutions scaled by the total number of shares outstanding

\section{Cartel Controls:}

Number_Participants: Number of firms involved in the cartel

Duration: Number of years from the beginning to the end of the cartel activities

Cartel_Sales: Total revenues of the cartel firms during the collusive period (in million dollars) 
Fines_Cartel: Total fines imposed on the cartel firms (in million dollars)

Leniency_Cartel: Indicator variable that equals one if the cartel prosecution was prompted by a leniency application, and zero otherwise

Fines_Firm_Pct: Total fines imposed on the firm divided by the sum of the fines imposed on the cartel firms

Recidivism: Number of times the firm has been prosecuted for involvement in prior cartels

Prosectution Effort:

Budget_Increase: Inflation-adjusted increase in the budget of the Antitrust Division of the DOJ

Punishment_Severity: Natural logarithm of the average fine imposed by the DOJ in that year

\section{Collusion Incentives:}

Herfindahl: Herfindahl index of the industry

Innovation: Industry average of the $\mathrm{R} \& \mathrm{D}$ expenses scaled by total assets

Barriers_to_Entry: Industry average of the PP\&E expenses scaled by total assets

Number_Competitors: Number of firms in the firm's 4-digit SIC code

Cost_Assymmetry: Industry standard deviation of COGS scaled by total assets

Market_Power: Industry average of the selling margin, computed as (sales revenues COGS) / sales revenues. Industry is defined by 4 -digit SIC code

Heterogeneity: Industry standard deviation of the selling margin, computed as (sales revenues - COGS) / sales revenues. Industry is defined by 4-digit SIC code

Demand_Growth: Percentage increase of industry sales

Demand_Volatility: Standard deviation of industry sales as percentage of total assets

Demand_Elasticity: Correlation between percentage changes in industry sales and percentage changes in the sum of sales across all Compustat firms

Diversification: The number of business segments in which the company operates. Industry is defined by 4-digit SIC code

\section{Director Controls:}

Age: Natural logarithm of one plus the age of the director

NBoards: Natural logarithm of one plus the number of directorships held by the director in a given year 
Table 1

\section{Summary Statistics}

This table reports descriptive statistics for our sample of firms prosecuted for cartel participation between 2002 and 2012. Panel A presents the industry distribution of the sample firms. Panel B reports descriptive statistics about selected characteristics of the sample firms. Panel $\mathrm{C}$ reports descriptive statistics about characteristics of the cartels in which the sample firms are involved. See Appendix A for variable definition.

\section{Panel A. Industry Distribution}

\begin{tabular}{lc}
\hline Fama-French 12 industry groups & \% of firms \\
\hline Business equipment & $6.28 \%$ \\
Chemicals and allied products & $9.42 \%$ \\
Consumer durables & $5.76 \%$ \\
Oil, gas, and coal extraction and products & $2.62 \%$ \\
Healthcare, medical equipment and drugs & $8.38 \%$ \\
Manufacturing & $14.14 \%$ \\
Financial firms & $18.85 \%$ \\
Consumer nondurables & $9.95 \%$ \\
Other & $14.14 \%$ \\
Wholesale, retail, and some services & $7.33 \%$ \\
Telephone and television transmission & $2.09 \%$ \\
Utilities & $1.05 \%$ \\
\hline Number of firms & 191 \\
\hline
\end{tabular}

\section{Panel B. Firm Characteristics}

\begin{tabular}{lrr}
\hline Variables & Mean & Median \\
\hline Firm_Controls: & & \\
$M V$ (millions) & 43,574 & 10,774 \\
BM & 0.53 & 0.44 \\
Leverage & 0.25 & 0.24 \\
Past_Return & 0.02 & 0.01 \\
ROA & 0.01 & 0.01 \\
Volatility & 0.02 & 0.02 \\
Governance_Controls: & & \\
Independent_Directors & 0.76 & 0.80 \\
Staggered & 0.34 & 0.00 \\
Chair_Insider & 0.85 & 1.00 \\
Busy_Directors & 0.60 & 0.63 \\
Age_69 & 0.13 & 0.11 \\
Indep_Director_Holdings (in \%) & 0.49 & 0.09 \\
Institutional_Holdings & 0.72 & 0.73 \\
\hline Firm-years with cartel prosecution & \multicolumn{2}{c}{519} \\
announcements & & \\
\hline
\end{tabular}


Table 1

Summary Statistics (cont'ed)

Panel C. Cartel Characteristics

\begin{tabular}{lrr}
\hline Cartel_Controls: & Mean & Median \\
\hline Cartel_Characteristics: & & \\
Number_Participants & 7.68 & 6 \\
Duration & 6.22 & 5 \\
Cartel_Sales & 49,385 & 3,885 \\
Fines_Cartel & 139 & 6.17 \\
Leniency_Cartel & 0.32 & 0 \\
Jurisdiction: & & 0 \\
$\quad$ USA & 0.43 & 0 \\
European Union & 0.15 & 0 \\
Canada & 0.33 & 0 \\
Other & 0.58 & \\
Cartel-Firm_Characteristics: & & 5.9 \\
Fines_Firm_Pct & 67.25 & \\
Recividism & 1.87 & \\
\hline Number of cartels & & 199 \\
\hline
\end{tabular}


Table 2

Abnormal Returns on Prosecution Announcement Days

This table presents results of analyzing cross-sectional variation in abnormal returns around news of cartel prosecution. The dependent variable Abnormal_Return is the market-adjusted return on each of the key dates of the cartel detection (expressed as a \%). The first set of columns (First Notices) includes first prosecution announcements in all the jurisdictions in which the cartel is prosecuted. The second set of columns $(A l l$ Prosecution Announcements) includes all prosecution announcements (i.e., including announcement of sanctions and terminations across all jurisdictions). The rest of the variables are as defined in Appendix A. The table presents the coefficient and $t$-statistic (in parenthesis) for each variable in the regression specification.

\begin{tabular}{|c|c|c|c|c|c|c|c|c|}
\hline \multirow[b]{3}{*}{ Independent Variables: } & \multicolumn{8}{|c|}{ Abnormal_Return } \\
\hline & \multicolumn{4}{|c|}{ First Notices } & \multicolumn{4}{|c|}{ All Prosecution Announcements } \\
\hline & $(1)$ & $(2)$ & $(3)$ & $(4)$ & $(5)$ & $(6)$ & $(7)$ & $(8)$ \\
\hline Independent_Directors & $\begin{array}{c}5.65^{* * *} \\
(3.26)\end{array}$ & $\begin{array}{c}5.15^{* * *} \\
(2.95)\end{array}$ & $\begin{array}{c}3.45^{* * *} \\
(2.61)\end{array}$ & $\begin{array}{c}4.00^{* * *} \\
(3.00)\end{array}$ & $\begin{array}{c}3.00^{* * *} \\
(2.90)\end{array}$ & $\begin{array}{c}2.58^{* *} \\
(2.48)\end{array}$ & $\begin{array}{c}2.35^{* * *} \\
(2.88)\end{array}$ & $\begin{array}{c}2.62^{* * *} \\
(3.04)\end{array}$ \\
\hline \multicolumn{9}{|l|}{ Firm_Controls } \\
\hline Size & & $\begin{array}{l}0.14^{*} \\
(1.67)\end{array}$ & $\begin{array}{c}0.21 \\
(1.02)\end{array}$ & $\begin{array}{c}0.12 \\
(0.70)\end{array}$ & & $\begin{array}{c}0.14^{* *} \\
(2.49)\end{array}$ & $\begin{array}{c}0.07 \\
(0.66)\end{array}$ & $\begin{array}{c}0.06 \\
(0.56)\end{array}$ \\
\hline$B M$ & & $\begin{array}{c}0.14 \\
(0.74)\end{array}$ & $\begin{array}{c}0.02 \\
(0.11)\end{array}$ & $\begin{array}{c}0.10 \\
(0.44)\end{array}$ & & $\begin{array}{c}0.16 \\
(0.98)\end{array}$ & $\begin{array}{c}0.11 \\
(0.70)\end{array}$ & $\begin{array}{c}0.11 \\
(0.65)\end{array}$ \\
\hline Past_Return & & $\begin{array}{c}1.72^{* * *} \\
(2.69)\end{array}$ & $\begin{array}{c}1.57^{* *} \\
(2.98)\end{array}$ & $\begin{array}{c}1.59^{* * *} \\
(2.61)\end{array}$ & & $\begin{array}{c}0.81^{* *} \\
(2.00)\end{array}$ & $\begin{array}{c}0.79^{* *} \\
(2.11)\end{array}$ & $\begin{array}{l}0.79^{*} \\
(1.91)\end{array}$ \\
\hline$R O A$ & & $\begin{array}{c}2.58^{* * *} \\
(3.03)\end{array}$ & $\begin{array}{c}2.16^{* *} \\
(2.30)\end{array}$ & $\begin{array}{c}0.98 \\
(1.02)\end{array}$ & & $\begin{array}{c}1.97^{* *} \\
(2.03)\end{array}$ & $\begin{array}{c}1.61 \\
(1.63)\end{array}$ & $\begin{array}{l}1.63^{*} \\
(1.75)\end{array}$ \\
\hline Leverage & & $\begin{array}{c}0.55 \\
(0.56)\end{array}$ & $\begin{array}{c}0.92 \\
(0.99)\end{array}$ & $\begin{array}{c}1.36 \\
(1.22)\end{array}$ & & $\begin{array}{c}0.65 \\
(1.03)\end{array}$ & $\begin{array}{c}0.77 \\
(1.22)\end{array}$ & $\begin{array}{c}0.91 \\
(1.20)\end{array}$ \\
\hline Volatility & & $\begin{array}{c}0.20 \\
(0.58)\end{array}$ & $\begin{array}{c}-0.17 \\
(-0.43)\end{array}$ & $\begin{array}{c}-0.36 \\
(-0.73)\end{array}$ & & $\begin{array}{c}0.27 \\
(1.21)\end{array}$ & $\begin{array}{c}0.11 \\
(0.49)\end{array}$ & $\begin{array}{c}-0.05 \\
(-0.19)\end{array}$ \\
\hline Governance_Controls & & & & & & & & \\
\hline Staggered & & & $\begin{array}{c}-0.31 \\
(-0.72)\end{array}$ & $\begin{array}{c}-0.44 \\
(-1.10)\end{array}$ & & & $\begin{array}{c}-0.38 \\
(-1.47)\end{array}$ & $\begin{array}{c}-0.33 \\
(-1.32)\end{array}$ \\
\hline Chair_Insider & & & $\begin{array}{c}-0.68^{*} \\
(-1.68)\end{array}$ & $\begin{array}{l}-0.60 \\
(-1.56)\end{array}$ & & & $\begin{array}{c}-0.04 \\
(-0.14)\end{array}$ & $\begin{array}{c}-0.06 \\
(-0.21)\end{array}$ \\
\hline Busy_Directors & & & $\begin{array}{l}-1.09 \\
(-1.17)\end{array}$ & $\begin{array}{l}-0.77 \\
(-0.84)\end{array}$ & & & $\begin{array}{l}-0.56 \\
(-1.04)\end{array}$ & $\begin{array}{c}-0.38 \\
(-0.69)\end{array}$ \\
\hline Age_69 & & & $\begin{array}{l}-3.49^{*} \\
(-1.83)\end{array}$ & $\begin{array}{l}-3.03^{*} \\
(-1.68)\end{array}$ & & & $\begin{array}{l}-1.85 \\
(-1.42)\end{array}$ & $\begin{array}{c}-1.64 \\
(-1.36)\end{array}$ \\
\hline Indep_Director_Holdings & & & $\begin{array}{c}0.04 \\
(0.32)\end{array}$ & $\begin{array}{c}0.11 \\
(0.88)\end{array}$ & & & $\begin{array}{c}-0.14^{* *} \\
(-2.06)\end{array}$ & $\begin{array}{c}-0.14^{*} \\
(-1.79)\end{array}$ \\
\hline Institutional_Holdings & & & $\begin{array}{c}2.23 \\
(1.31)\end{array}$ & $\begin{array}{c}1.03 \\
(0.67)\end{array}$ & & & $\begin{array}{c}0.26 \\
(0.32)\end{array}$ & $\begin{array}{c}0.03 \\
(0.05)\end{array}$ \\
\hline Cartel_Controls & & & & & & & & \\
\hline Number_Participants & & & $\begin{array}{c}-0.16 \\
(-0.53)\end{array}$ & $\begin{array}{c}-0.07 \\
(-0.28)\end{array}$ & & & $\begin{array}{c}0.02 \\
(0.13)\end{array}$ & $\begin{array}{c}0.03 \\
(0.20)\end{array}$ \\
\hline Duration & & & $\begin{array}{l}-0.57^{*} \\
(-1.72)\end{array}$ & $\begin{array}{c}-0.49 \\
(-1.06)\end{array}$ & & & $\begin{array}{c}-0.18 \\
(-0.87)\end{array}$ & $\begin{array}{c}-0.13 \\
(-0.44)\end{array}$ \\
\hline Cartel_Sales & & & $\begin{array}{c}-0.11 \\
(-1.48)\end{array}$ & $\begin{array}{c}-0.11 \\
(-1.46)\end{array}$ & & & $\begin{array}{c}-0.09^{* *} \\
(-2.09)\end{array}$ & $\begin{array}{l}0.12^{\text {** }} \\
(-2.43)\end{array}$ \\
\hline Fines_Cartel & & & $\begin{array}{c}0.05 \\
(0.45)\end{array}$ & $\begin{array}{c}0.04 \\
(0.41)\end{array}$ & & & $\begin{array}{c}0.02 \\
(0.29)\end{array}$ & $\begin{array}{c}0.04 \\
(0.66)\end{array}$ \\
\hline Fines_Firm_Pct & & & $\begin{array}{c}-5.15^{* * *} \\
(-3.00)\end{array}$ & $\begin{array}{c}-4.99 * * * \\
(-2.79)\end{array}$ & & & $\begin{array}{c}-2.61^{* *} \\
(-2.52)\end{array}$ & $\begin{array}{c}-2.58^{* *} \\
(-2.38)\end{array}$ \\
\hline Recividism & & & $\begin{array}{c}0.24 \\
(0.88)\end{array}$ & $\begin{array}{c}0.46 \\
(1.54)\end{array}$ & & & $\begin{array}{c}0.24 \\
(1.37)\end{array}$ & $\begin{array}{c}0.41^{* *} \\
(2.31)\end{array}$ \\
\hline Fixed_Effects & & & & & & & & \\
\hline Jurisdiction-Fixed Effects & & & & YES & & & & YES \\
\hline Year-Fixed Effects & & & & YES & & & & YES \\
\hline Industry-Fixed Effects & & & & YES & & & & YES \\
\hline Observations & 547 & 547 & 547 & 547 & 1,028 & 1,028 & 1,028 & 1,028 \\
\hline R-squared & 0.05 & 0.08 & 0.14 & 0.17 & 0.02 & 0.03 & 0.06 & 0.08 \\
\hline
\end{tabular}


Table 3

Heckman's Sample Selection Model

This table presents results of analyzing abnormal returns around news of cartel prosecution using a Heckman sample selection model. The first-stage regression models the inclusion of a firm in the sample, that is, the probability of prosecution. The second-stage regression models average abnormal returns for each firmcartel prosecution. In the first stage, the dependent variable Prosecuted equals one if the firm is involved in a cartel detected in year $t$, and zero otherwise. For prosecuted firms, the panel only includes years in which cartels are detected (i.e., cartel prosecution is announced for the first time). For unprosecuted firms, the tests include all year observations between 2002 and 2012. In the second stage the dependent variable Abnormal_Return is computed for each firm-cartel observation as the average market-adjusted return to prosecution announcements related to the prosecution of the firm for a given cartel (expressed as a \%), including all jurisdictions in which the firm was prosecuted. In the first set of columns (First Notice) Abnormal_Return is computed including only first prosecution announcements related to a given cartel. In the second set of columns (All Prosecution Announcements) Abnormal_Return is computed including all prosecution announcements. The second stage includes the inverse Mills ratio (Inverse_Mills_Ratio) as an additional explanatory variable. Inverse_Mills_Ratio is constructed based on coefficient estimates of the first-stage regression predicting whether a firm is subject to cartel prosecution. The rest of the variables are as defined in Appendix A. All independent variables are measured at the start of the year. The first set of columns (First Notices) includes first prosecution announcements in all the jurisdictions in which the cartel was prosecuted. The second set of columns (All Prosecution Announcements) includes all prosecution announcements (i.e., including announcement of sanctions and terminations across all jurisdictions). The table presents the coefficient and $z$-statistic (in parenthesis) for each variable in the regression specification. 


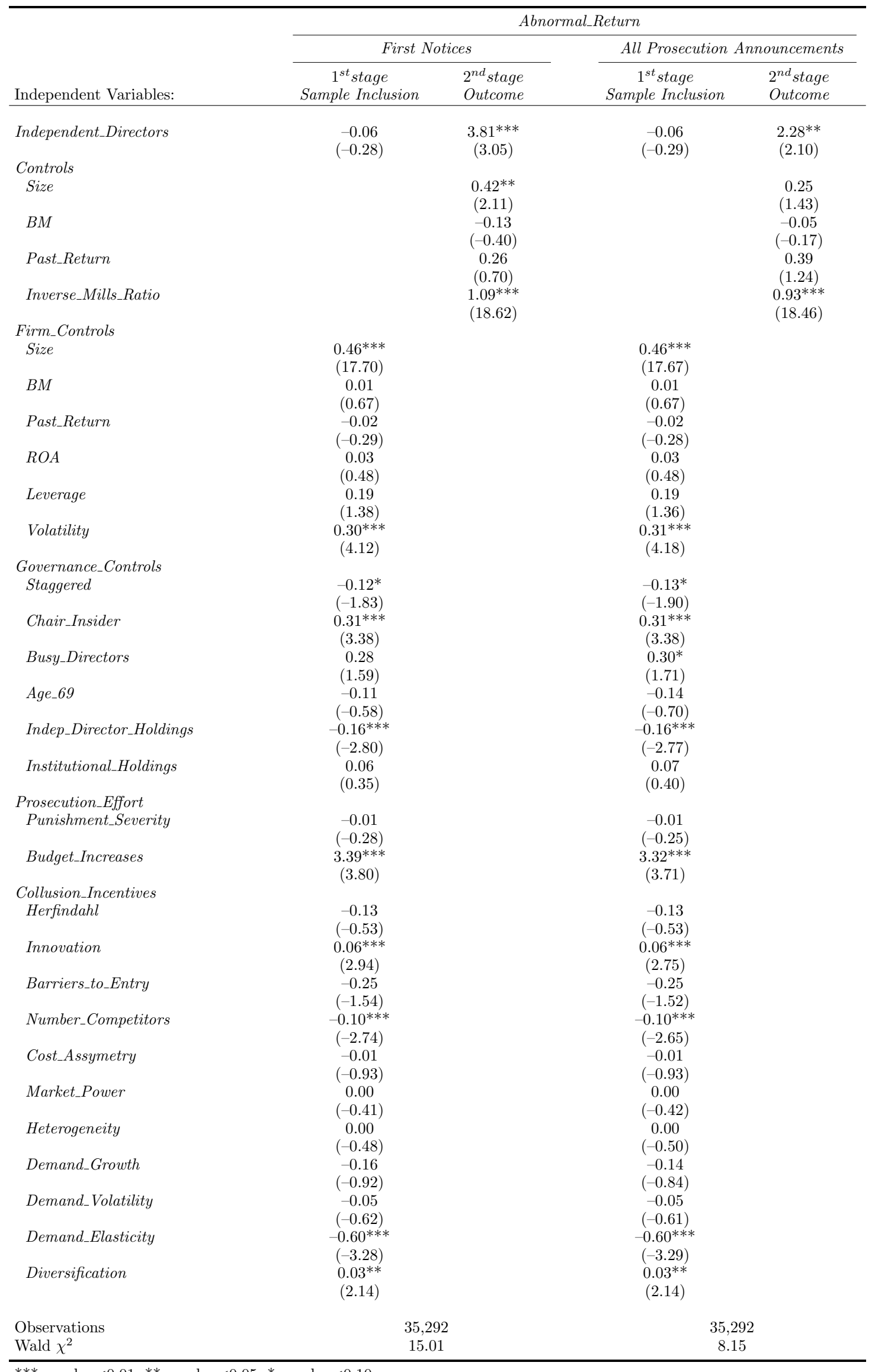

*** $p$-value $<0.01,{ }^{* *} p$-value $<0.05,{ }^{*} p$-value $<0.10$ 
Table 4

Sources of Variation in the Percentage of Independent Directors

This table presents results of the association between prosecution announcement returns and sources of variation in the percentage of independent directors. Abnormal_Return is the firm's market-adjusted return on the first notice of cartel prosecution in each jurisdiction (expressed as a \%). Independent_Appointment is computed as the number of independent directors appointed under the circumstances listed below divided by the total number of directors. (1) Appointed at the passage of SOX equals one if the appointment of the independent director occurred in 2002 (year of the passage of Sarbanes Oxley) and if the audit committee was not fully independent at the start of 2001, and zero otherwise. (2) Appointed before the CEOs tenure equals one if the appointment of the independent director occurred before the appointment of the current CEO, and zero otherwise. (3) Appointed in difficult times equals one if the industry returns over the 12 months prior to the appointment of the independent director are negative, and zero otherwise. (4) Appointed after class action suits equals one if the firm was subject to shareholder litigation during the 12 months prior to the appointment of the independent director, and zero otherwise. (5) Appointed under voting concerns equals one if directors experienced a decrease of more than $1 \%$ in voting support at the prior election or if ISS issued a "withhold" recommendation for any of the directors, and zero otherwise. These circumstances reflect situations in which the appointment is less likely to be driven by current managements personal interests. In model (1), Independent_Appointment is computed as the number of independent directors appointed under at least one of the circumstances listed above divided by the total number of directors. In model (2), Independent_Appointment is computed as the number of independent directors appointed under at least two of the circumstances listed above divided by the total number of directors. In model (3), Independent_Appointment is computed as the number of independent directors appointed under at least three of the circumstances listed above divided by the total number of directors. The rest of the variables are as defined in Appendix A.

\begin{tabular}{lccc}
\hline & \multicolumn{3}{c}{ Abnormal_Return } \\
Number of circumstances: & At least 1 & At least 2 & At least 3 \\
Independent Variables: & $(1)$ & $(2)$ & $(3)$ \\
\hline & & $1.88^{* *}$ & $2.43^{* *}$ \\
Independent_Appointment & $1.72^{* * *}$ & $(2.53)$ & $(2.27)$ \\
Size & $(3.00)$ & 0.10 & 0.16 \\
& 0.11 & $(0.69)$ & 0.05 \\
BM & $(0.93)$ & 0.06 & $(0.28)$ \\
Past_Return & 0.11 & $(0.34)$ & $1.81^{* * *}$ \\
& $(0.54)$ & $1.88^{* * *}$ & $(2.66)$ \\
Observations & $1.77^{* * *}$ & $(2.88)$ & 547 \\
R-squared & $(2.63)$ & 547 & 0.04 \\
\hline *** $p$-value $<0.01, * *$ & & 0.04 & \\
\hline
\end{tabular}

$* * * p$-value $<0.01, * * p$-value $<0.05, * p$-value $<0.10$ 


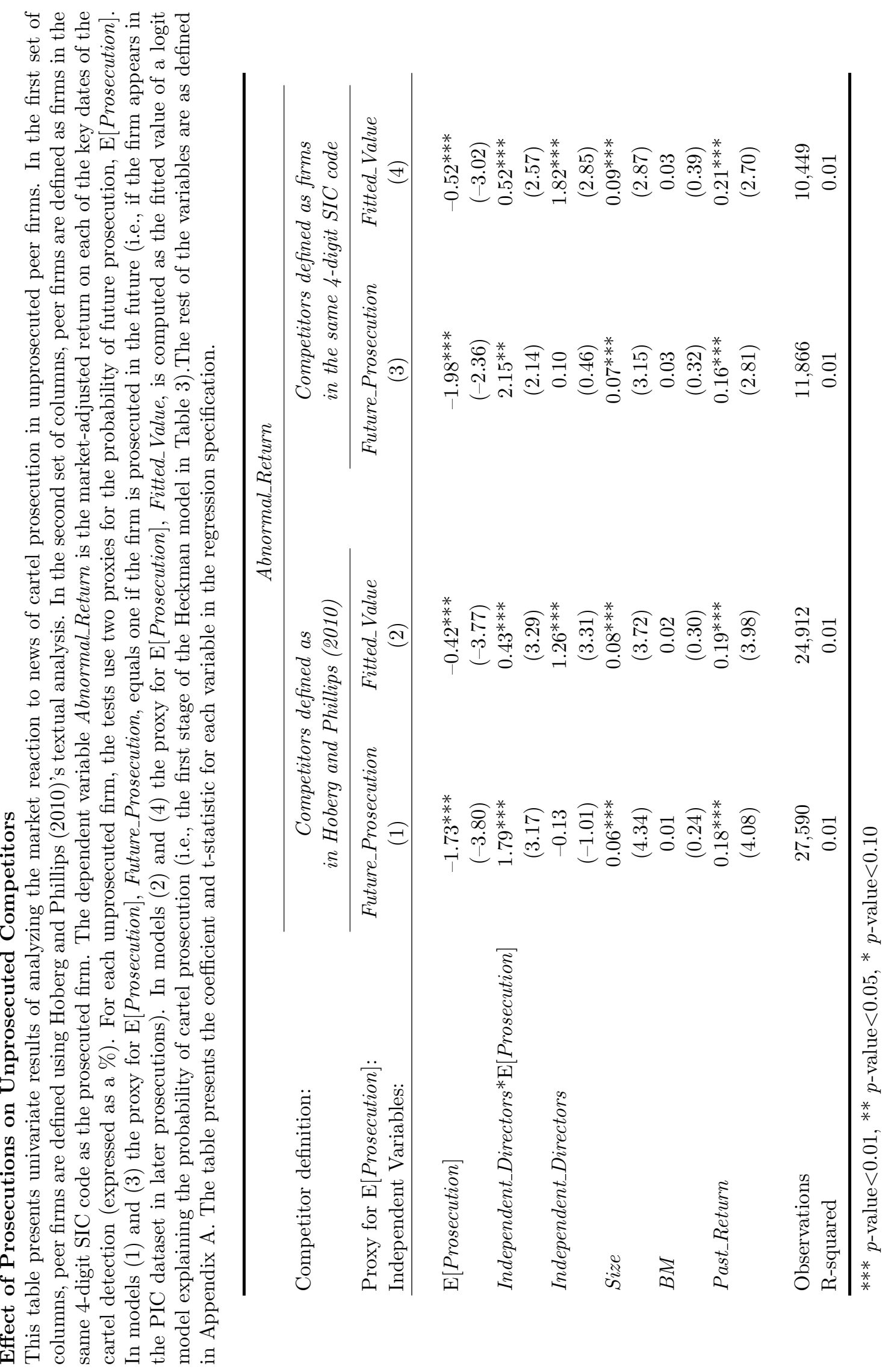




\section{Table 6}

\section{Independent Directors' Incentives}

This table presents results of analyzing abnormal returns around news of cartel prosecution. The dependent variable Abnormal_Return is the market-adjusted return on prosecution announcement days (expressed as a \%). Other_Boards is the value-weighted average number of outside boards (i.e., other than the prosecuted firm) on which the firm's outside directors serve. Columns (1) and (2) present the results of partitioning the sample into firms in the top (High) and bottom (Low) tertiles of Other_Boards. Stock_Options is the number of stock options held by the firm's outside directors scaled by the number of shares held by the firm's outside directors. Columns (3) and (4) present the results of partitioning the sample into firms in the top (High) and bottom (Low) tertiles of Stock_Options. The rest of the variables are as defined in Appendix A. The table presents the coefficient and $t$-statistic for each variable in the regression specification.

\begin{tabular}{|c|c|c|c|c|}
\hline \multirow{3}{*}{$\begin{array}{l}\text { Measure of director incentives: } \\
\text { Independent Variables: }\end{array}$} & \multicolumn{4}{|c|}{ Abnormal_Return } \\
\hline & \multicolumn{2}{|c|}{ Other_Boards } & \multicolumn{2}{|c|}{ Stock_Options } \\
\hline & $\begin{array}{c}\text { Low }(L) \\
(1)\end{array}$ & $\begin{array}{c}\operatorname{High}(H) \\
(2)\end{array}$ & $\begin{array}{c}\operatorname{Low}(L) \\
(3)\end{array}$ & $\begin{array}{c}\operatorname{High}(H) \\
(4)\end{array}$ \\
\hline Independent_Directors & $\begin{array}{c}4.37^{* *} \\
(2.47)\end{array}$ & $\begin{array}{c}11.64^{* * *} \\
(4.90)\end{array}$ & $\begin{array}{c}13.35^{* * *} \\
(5.14)\end{array}$ & $\begin{array}{c}0.94 \\
(0.86)\end{array}$ \\
\hline Size & $\begin{array}{l}0.34^{*} \\
(1.92)\end{array}$ & $\begin{array}{l}-0.08 \\
(-0.51)\end{array}$ & $\begin{array}{c}0.05 \\
(0.28)\end{array}$ & $\begin{array}{c}0.08 \\
(0.79)\end{array}$ \\
\hline$B M$ & $\begin{array}{c}0.07 \\
(0.25)\end{array}$ & $\begin{array}{c}0.29 \\
(0.83)\end{array}$ & $\begin{array}{c}0.22 \\
(0.51)\end{array}$ & $\begin{array}{c}0.61 \\
(0.96)\end{array}$ \\
\hline Past_Return & $\begin{array}{l}2.08^{*} \\
(1.80)\end{array}$ & $\begin{array}{c}0.86 \\
(1.00)\end{array}$ & $\begin{array}{c}3.30 * * * \\
(3.73)\end{array}$ & $\begin{array}{c}-1.29 \\
(-1.52)\end{array}$ \\
\hline $\begin{array}{l}\text { Observations } \\
\text { R-squared }\end{array}$ & $\begin{array}{c}191 \\
0.08\end{array}$ & $\begin{array}{r}186 \\
0.12\end{array}$ & $\begin{array}{l}185 \\
0.18\end{array}$ & $\begin{array}{c}179 \\
0.02\end{array}$ \\
\hline $\begin{array}{l}\text { Test of equality of coefficients on } \\
\text { Independent_Directors in } H \text { and } L[p \text {-value }]\end{array}$ & & & & \\
\hline
\end{tabular}

$* * * p$-value $<0.01,{ }^{* *} p$-value $<0.05,{ }^{*} p$-value $<0.10$ 


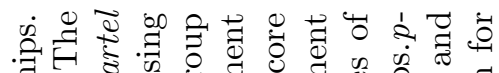

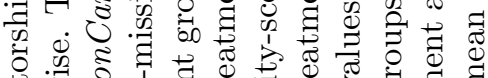
융

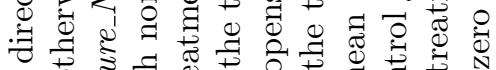

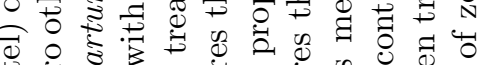

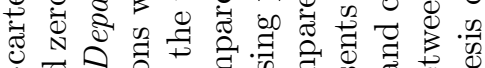
i 00.000

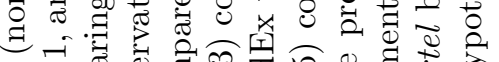

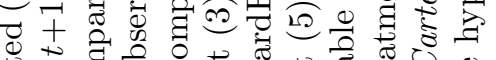

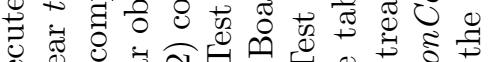

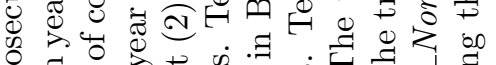

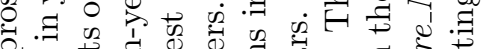

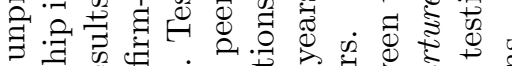

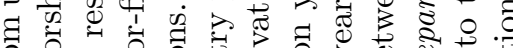

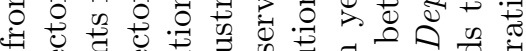
. o tu

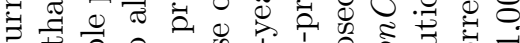
녕워 엽

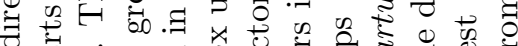

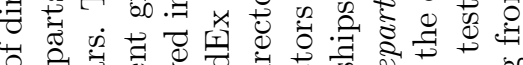
o $=$

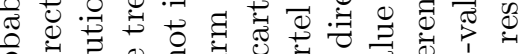

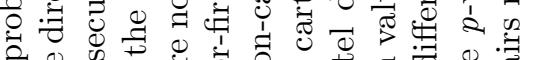

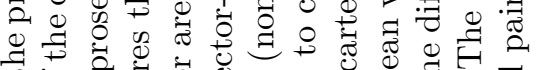

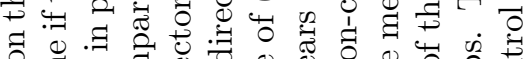
of

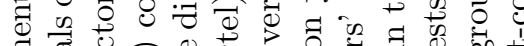

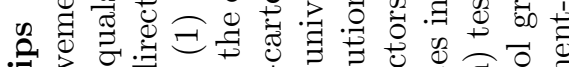
承

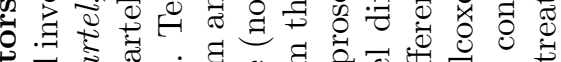

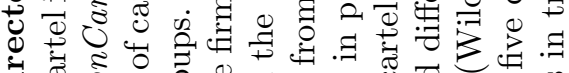

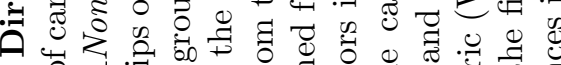
o

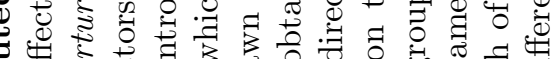
o t ष

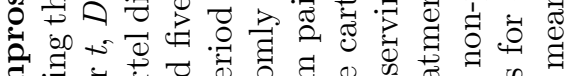

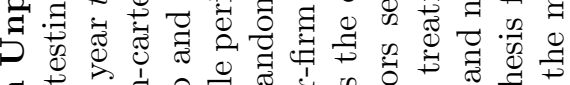

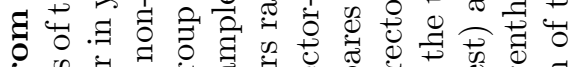

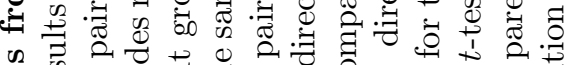

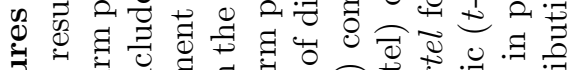

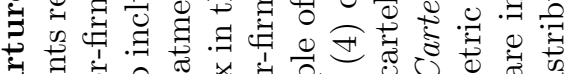

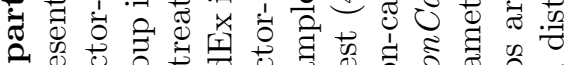

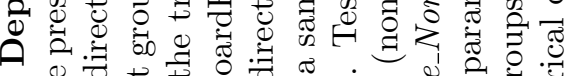

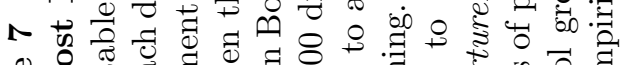

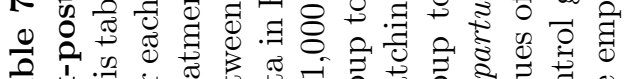

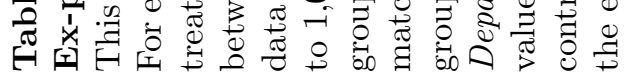

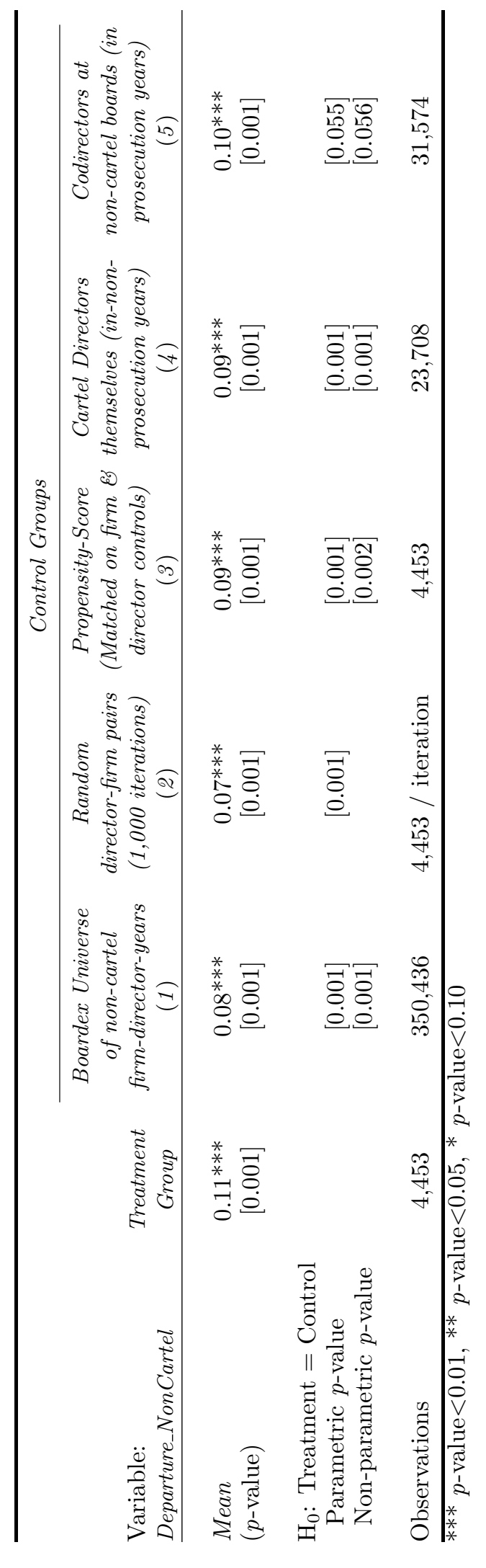




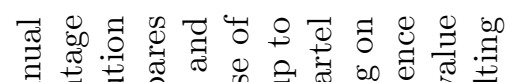

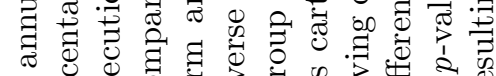

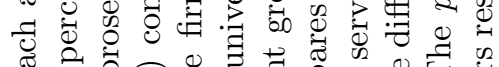

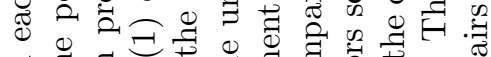

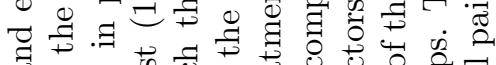

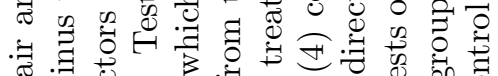
光 ธे

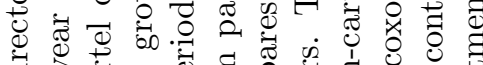

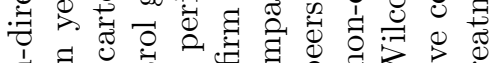

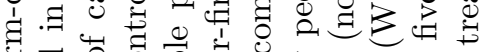

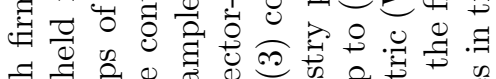

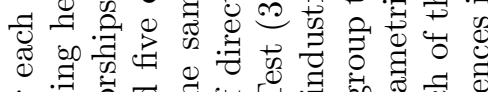

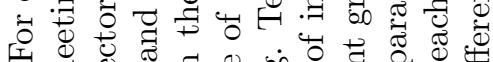
. 范

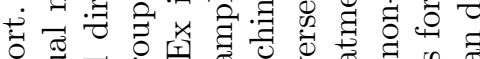

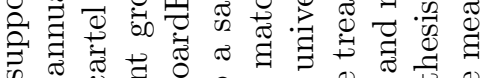

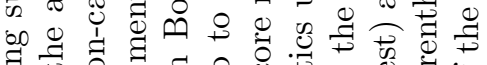

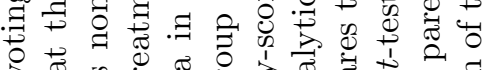

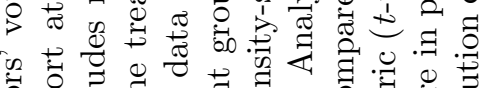
○े

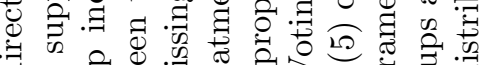
$\exists$ की

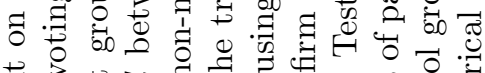

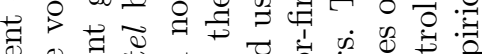

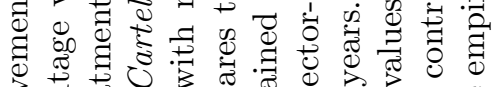

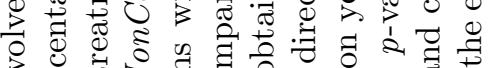

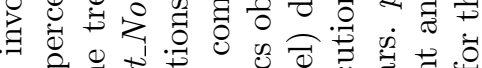

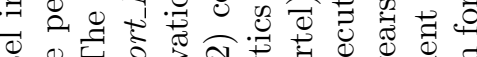
密 đٓं

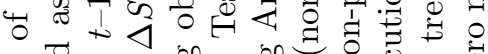
U

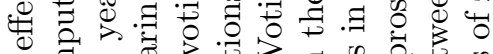
\&

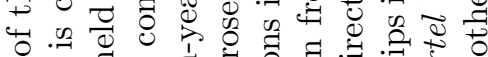
०. - 4 है

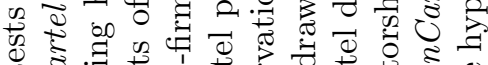

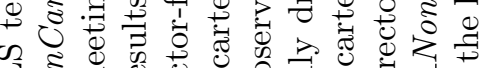

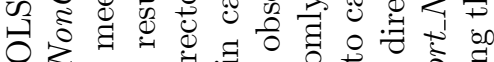

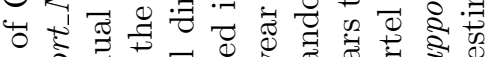

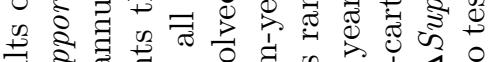

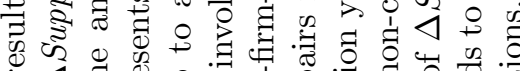

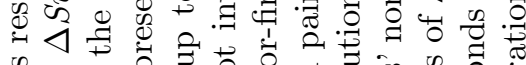

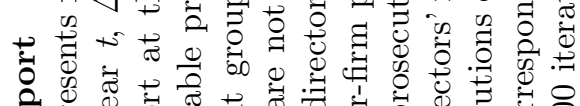

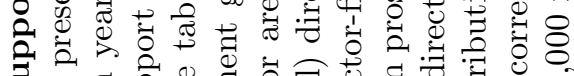

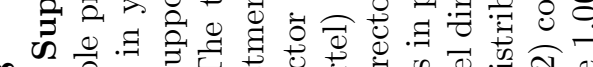

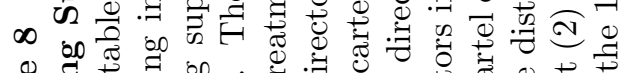

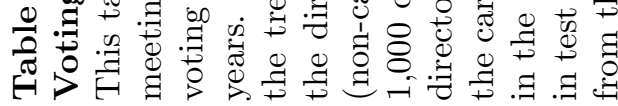

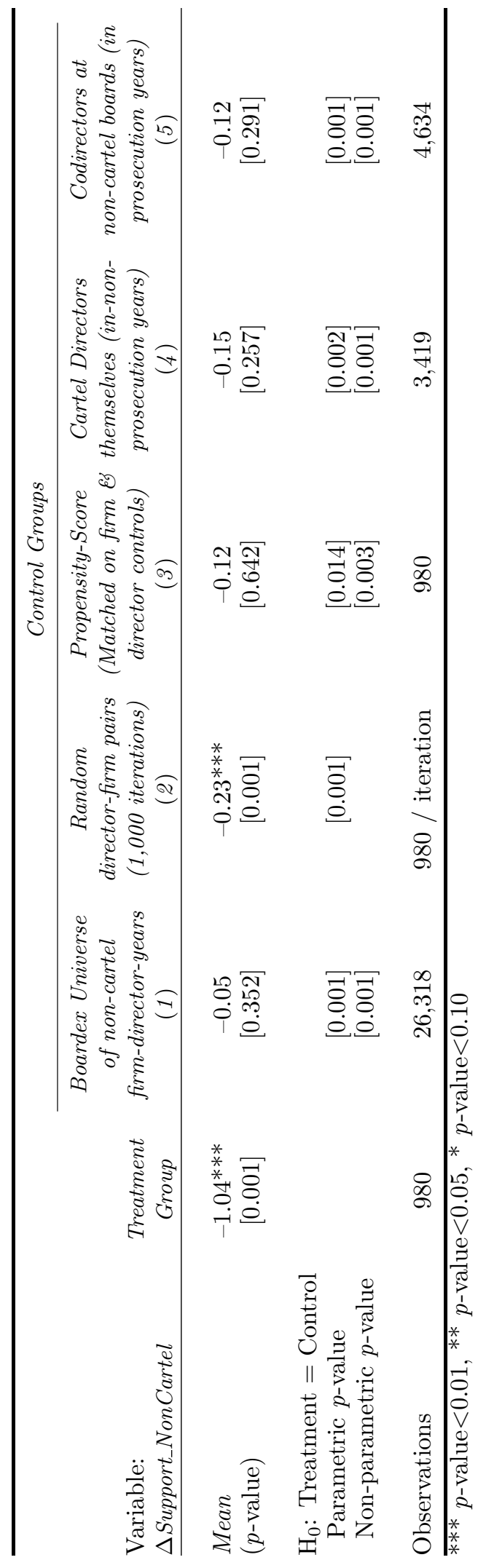


Table 9

\section{Leniency Applications}

This table presents results of OLS tests of the association between the probability of applying for leniency and the presence of independent directors on the board. The dependent variable Leniency equals one if the company applies for leniency, and zero otherwise. Firm_Controls includes Size, BM, Leverage, Past_Return, $R O A$, and the natural logarithm of Volatility. Governance_Controls includes Chair_Insider, Staggered, Busy_Directors, Age_69, Indep_Director_Holdings, and Institutional_Holdings. Cartel_Controls includes the logarithmic transformations of Number_Participants, Duration, Cartel_Sales, Fines_Cartel, Fines_Firm_Pct, and Recidivism. All these variables are defined in Appendix A. The table presents the coefficient and $t$ statistic (in parenthesis) for each variable in the regression specification.

\begin{tabular}{lcccc}
\hline & \multicolumn{4}{c}{ Leniency } \\
\cline { 2 - 5 } Independent Variables: & $(1)$ & $(2)$ & $(3)$ & $(4)$ \\
\hline & $0.15^{* *}$ & $0.22^{* * *}$ & $0.13^{* *}$ & $0.15^{*}$ \\
Independent_Directors & $(2.32)$ & $(3.33)$ & $(1.99)$ & $(1.77)$ \\
& & YES & YES & YES \\
Firm_Controls & & YES & YES \\
Governance_Controls & & YES & YES \\
Cartel_Controls & & & YES \\
Jurisdiction-Fixed Effects & & & YES \\
Year-Fixed Effects & & & YES \\
Industry-Fixed Effects & 585 & 585 & 585 & 585 \\
& 0.01 & 0.12 & 0.29 & 0.38 \\
Observations & & & & \\
R-squared & & & & \\
\hline
\end{tabular}

${ }^{* * *} p$-value $<0.01,{ }^{* *} p$-value $<0.05,{ }^{*} p$-value $<0.10$ 
Table 10

\section{Ex-post CEO Turnover}

This table presents results of OLS tests of the association between CEO turnover after cartel prosecution announcements and the presence of independent directors on the board. The dependent variable, CEO_Turnover, equals one if the CEO leaves the firm during the 12 months after the announcement of the cartel detection, and zero otherwise. Independent_Directors is the percentage of independent directors on the board. Firm_Controls includes Size, BM, Leverage, Past_Return, ROA, and the natural logarithm of Volatility. Governance_Controls includes Chair_Insider, Staggered, Busy_Directors, Age_69, Indep_Director_Holdings, and Institutional_Holdings. Cartel_Controls includes the logarithmic transformations of Number_Participants, Duration, Cartel_Sales, Fines_Cartel, Fines_Firm_Pct, and Recidivism. All these variables are defined in Appendix A. The table presents the coefficient and $t$-statistic (in parenthesis) for each variable in the regression specification.

\begin{tabular}{|c|c|c|c|c|}
\hline \multirow[b]{2}{*}{ Independent Variables: } & \multicolumn{4}{|c|}{ CEO_Turnover } \\
\hline & (1) & $(2)$ & $(3)$ & (4) \\
\hline Independent_Directors & $\begin{array}{c}0.17^{* *} \\
(2.41)\end{array}$ & $\begin{array}{c}0.16^{* *} \\
(2.15)\end{array}$ & $\begin{array}{l}0.17^{*} \\
(1.85)\end{array}$ & $\begin{array}{l}0.20^{*} \\
(1.92)\end{array}$ \\
\hline Firm_Controls & & YES & YES & YES \\
\hline Governance_Controls & & & YES & YES \\
\hline Cartel_Controls & & & YES & YES \\
\hline Jurisdiction-Fixed Effects & & & & YES \\
\hline Year-Fixed Effects & & & & YES \\
\hline Industry-Fixed Effects & & & & YES \\
\hline Observations & 519 & 519 & 519 & 519 \\
\hline R-squared & 0.01 & 0.02 & 0.04 & 0.08 \\
\hline
\end{tabular}

$* * * p$-value $<0.01,{ }^{* *} p$-value $<0.05,{ }^{*} p$-value $<0.10$ 